Review

\title{
Some Common Medicinal Plants with Antidiabetic Activity, Known and Available in Europe (A Mini-Review)
}

\author{
Monika Przeor (D) \\ Department of Gastronomy Science and Functional Foods, Poznań University of Life Sciences, \\ 60-637 Poznań, Poland; monika.przeor@up.poznan.pl; Tel.: +48-61-846-63-30
}

check for updates

Citation: Przeor, M. Some Common Medicinal Plants with Antidiabetic Activity, Known and Available in Europe (A Mini-Review). Pharmaceuticals 2022, 15, 65. https:// doi.org/10.3390/ph15010065

Academic Editor: Daniela De Vita

Received: 8 November 2021

Accepted: 15 December 2021

Published: 4 January 2022

Publisher's Note: MDPI stays neutral with regard to jurisdictional claims in published maps and institutional affiliations.

Copyright: (C) 2022 by the author Licensee MDPI, Basel, Switzerland. This article is an open access article distributed under the terms and conditions of the Creative Commons Attribution (CC BY) license (https:// creativecommons.org/licenses/by/ $4.0 /)$

\begin{abstract}
Diabetes is a metabolic disease that affected 9.3\% of adults worldwide in 2019. Its cooccurrence is suspected to increase mortality from COVID-19. The treatment of diabetes is mainly based on the long-term use of pharmacological agents, often expensive and causing unpleasant side effects. There is an alarming increase in the number of pharmaceuticals taken in Europe. The aim of this paper is to concisely collect information concerning the few antidiabetic or hypoglycaemic raw plant materials that are present in the consciousness of Europeans and relatively easily accessible to them on the market and sometimes even grown on European plantations. The following raw materials are discussed in this mini-review: Morus alba L., Cinnamomum zeylanicum J.Presl, Trigonella foenum-graecum L., Phaseolus vulgaris L., Zingiber officinale Rosc., and Panax ginseng C.A.Meyer in terms of scientifically tested antidiabetic activity and the presence of characteristic biologically active compounds and their specific properties, including antioxidant properties. The characteristics of these raw materials are based on in vitro as well as in vivo studies: on animals and in clinical studies. In addition, for each plant, the possibility to use certain morphological elements in the light of EFSA legislation is given.
\end{abstract}

Keywords: antidiabetic; hypoglycaemic activity; medicinal plants; white mulberry; fenugreek; cinnamon; ginseng; ginger; common bean; diabetes

\section{Introduction}

Diabetes mellitus is a serious metabolic disorder. The reason for chronic hyperglycaemia can be: (1) a lack of production of an adequate amount of insulin or (2) the impossibility of peripheral tissues to react to the presence of insulin [1].

Diabetes mellitus spreads rapidly. In 2019,9.3\% of the global adult population were found to be diabetic [2]. The International Diabetes Federation in 2017 reported that the risk of type 2 diabetes concerned 352 million people. According to health forecasts, 439 million adults will have been affected by diabetes by the year 2030 [3]. Mortality from diabetes in 2010 ranged from 6\% of all deaths in Africa to $15.7 \%$ of all deaths recorded in North America [4], and a meta-analysis of studies conducted during the COVID-19 pandemic showed that diabetes increases mortality in patients with COVID-19 [5]. The need to slow down the development of diabetes seems to be significant for maintaining the homeostasis of society in the world, also in view of the possibility of new pathogens and diseases. The overlapping of many diseases can result in irreversible health damage.

Historical reports and centuries-old cultural traditions show that some plants can be an alternative to standard pharmacotherapy or, at least, help with treatment or have a preventative effect. Modern science is very eager to verify these properties by analyzing the so-called medicinal plants for the presence of valuable bioactive compounds, including antioxidants, and the resulting interesting potential health properties [6-14]. In order for them to be introduced into the diet, their purity in terms of toxic compounds must also be taken into account $[15,16]$.

There are different possible ways of introducing such plants into the diet. In Table 1 , two different ways are shown. 
Table 1. Different possible ways of introducing medicinal plants into the diet.

\begin{tabular}{|c|c|c|}
\hline \multicolumn{3}{|c|}{ How Can the Medicinal Plant Be Introduced into the Diet? } \\
\hline & First way & \\
\hline \multirow{3}{*}{ Eat on your own } & Basic form: & $\begin{array}{c}\text { whole leaves } \\
\text { whole seeds } \\
\text { whole shoots } \\
\text { whole fruits }\end{array}$ \\
\hline & Modified form: & $\begin{array}{l}\text { ground } \\
\text { crushed } \\
\text { dried } \\
\text { cut }\end{array}$ \\
\hline & Changed state of matter: & $\begin{array}{c}\text { brew } \\
\text { tea } \\
\text { extract }\end{array}$ \\
\hline \multicolumn{3}{|c|}{ Second way } \\
\hline Change the matrix & $\begin{array}{l}\text { Functional food products } \\
\text { Dietary supplements }\end{array}$ & \\
\hline
\end{tabular}

The first way is to eat them on our own in a basic or modified form or in a slightly changed state of matter. The second way to use raw plant materials with antidiabetic activity is to change the matrix of the given substance, i.e., producing dietary supplements or designing foods containing a given raw material and giving them strictly defined characteristics, i.e., producing so-called functional food. This type of food is aimed at people with elevated blood glucose levels and used in the manufacture of food for obese patients. Technologists design such food products [17], and consumers increasingly seek such food [18]. In recent years, there has been a considerable and observable emphasis, or at least fashion, as to the maintenance of full health and vitality even in old age.

Although oral administration is the most common and simplest (for an average patient) way of introducing such raw materials into the human gastrointestinal tract, other ways of administration of such plants are also being analyzed [19,20].

There are many conventional pharmaceuticals for diabetes available on the market; however, their prices and the possible side-effects of long-term intake force the search for plant substitutes.

\section{Medicinal Plants with Antidiabetic Activity}

Many plants are rich sources of bioactive compounds with specific pharmacological properties, and they do not cause undesirable side effects [21,22]. For many years, the communities of developing countries have placed high hopes on these plant treatments, and the use of cheap medicinal plants instead of drugs to treat diabetes is common there [23]. At present, developed countries are also more inclined to adopt such solutions.

Medicinal plants contain various phytoconstituents (e.g., terpenoids, saponins, flavonoids, carotenoids, alkaloids, glycosides) with antidiabetic activity [14,24-26]. The complex plant matrix is a carrier of many phytoconstituents, which determines the specific interaction of these compounds; this is, however, difficult to reproduce and brings health benefits [27]. Chan et al. [28] noted in their work that antidiabetic ingredients are definitely most frequently found in leaves (more than 35\% of the analyzed plants), while in other morphological elements are 3 times less frequent (about 10\% each).

Based on the literature review [28], six general antidiabetic mechanisms of active pharmaceuticals can be specified:

1. Alteration of glucose metabolism: inhibition of renal reabsorption of glucose [29], inhibition of $\beta$-galactosidase [30], inhibition of $\beta$-glucosidase $[30,31]$, inhibition of $\alpha$-amylase [30,31], glycogenesis stimulation [32], hepaticglycolysis stimulation [32], starch conversion to glucose inhibited [30,31]; 
2. Hypolipidemic effect: lipid peroxidation decrease [33];

3. Pancreatic effect: effect of regeneration/repairing of $\beta$-cells [34], protective effect on $\beta$-cells [35], effect of increasing number and/or size of cells in Langerhans islets [34], insulin resistance reduction [36], insulin secretion stimulation [36,37], inhibition of degradative processes of insulin [36];

4. Antioxidative effect: protection against the effects of oxidative stress responsible for $\beta$-cell dysfunction [38] by scavenging free radicals, reducing $\mathrm{H}_{2} \mathrm{O}_{2}$ formation, inhibition of ROS production, modulation of enzymes (cyclooxygenase, microsomal monooxygenase, NADH oxidase, xanthine oxidase, lipoxygenase, succinoxidase) [39], regulation of antioxidant:oxidant balance in cells [33], induction of enzymes (glutathione peroxidase, catalase, superoxide dismutase) [33], improvement of antioxidant capacity in plasma [33];

5. Diabetes complication treatment: inhibition of pro-inflammatory pathway of NF- $\kappa \beta$, resulting in vascular complications [40];

6. Insulin-like effect.

Alternation of glucose metabolism is the most common one. The use of medicinal plants based on this most common scheme is mainly based on supporting pancreatic function-increasing insulin secretion or decreasing intestinal glucose uptake [21,23].

Therefore, inhibitors that interfere with digestive enzymes, which are responsible for the hydrolysis and absorption of macroelements, are important. The problems with the maintenance of normal glycaemia can be reduced by inhibition of enzymes digesting carbohydrates: pancreatic $\alpha$-amylase (breakdown of polysaccharides to oligosaccharides and disaccharides) and brush border $\alpha$-glucosidase (breakdown to monosaccharides) [41]. Some studies suggest that the most significant natural inhibitors, due to their presence in many antidiabetic plants, are terpenes, saponins, and polyphenols [41-44]. The literature presents many medicinal plants with antidiabetic or antihyperglycaemic activity, used in different regions of the world. Recently, Salehi et al. [21] indicated 703 plants as being $\alpha$-amylase and/or $\alpha$-glucosidase inhibitors and most often discussed in the literature.

This review describes some antidiabetic medicinal plants (white mulberry, fenugreek, cinnamon, common bean, ginger, and ginseng) widely available, quite cheap for the average consumers, and trusted by Europeans, especially in Central Europe.

\subsection{White Mulberry (Morus alba L.)}

Mulberry is a fast-growing, deciduous plant from the Moraceae family that is found at various geographical latitudes, i.e., in climates from tropical to moderate [45].

White mulberry originates from China, Japan, and India, and historical sources have revealed that all its parts, i.e., fruits, leaves, and bark, were already used in medicine in 3000 B.C. It was brought to Europe in the 11th century with silkworm caterpillars. It is also very common in other countries of Asia, Europe, and America [46]. White mulberry is also grown in Europe due to low agrotechnical requirements, relatively easy and cheap cultivation, and the possibility of using it in the food industry [47-50].

Mulberry leaves contain nutrients such as proteins, lipids, carbohydrates, fiber, $\beta$ carotene, xanthophylls, vitamin $C$, and complex vitamins, including folic acid, vitamins $\mathrm{D}$ and $\mathrm{E}, \beta$-sitosterol, and minerals $[11,14,51]$. Mulberry leaves are also rich in valuable compounds of pharmacological activity, including polyphenolic compounds such as quercetin 3-(6-malonyl-glucoside), kaempferol 3-(6-malonyl-glucoside), rutin, morcetin, isoquercetin, astragalin, and other glycosides, tannins, and coumarins, as well as phenolic acids $[14,25,52]$. The most common biologically active compounds present in white mulberry and defined as probably antidiabetic are shown in Table 1. 
Table 1. The most common biologically active compounds identified as probably antidiabetic in medicinal plants.

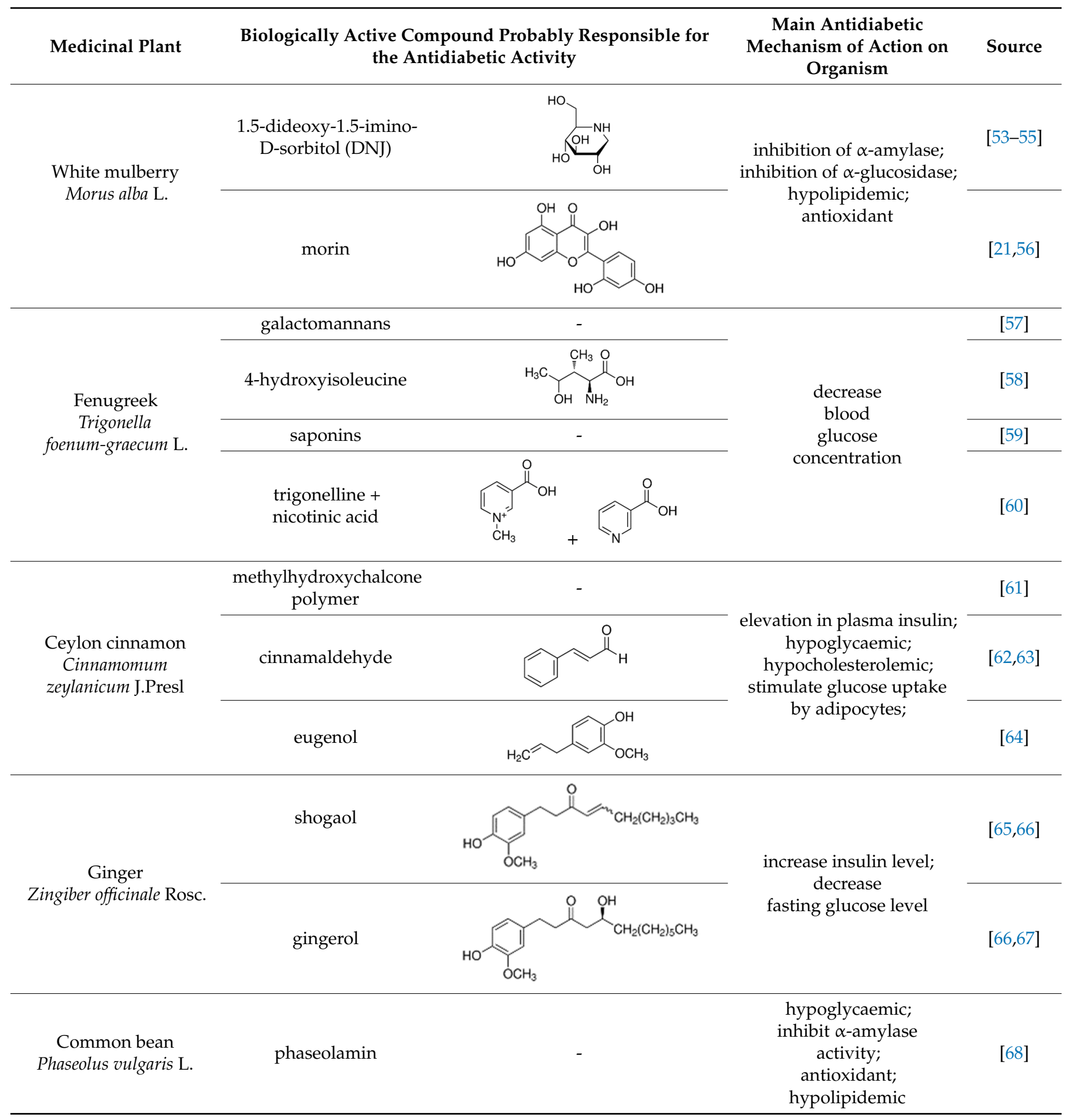


Table 1. Cont.

Biologically Active Compound Probably Responsible for the Antidiabetic Activity
Main Antidiabetic

Mechanism of Action on Organism
Source

(a)

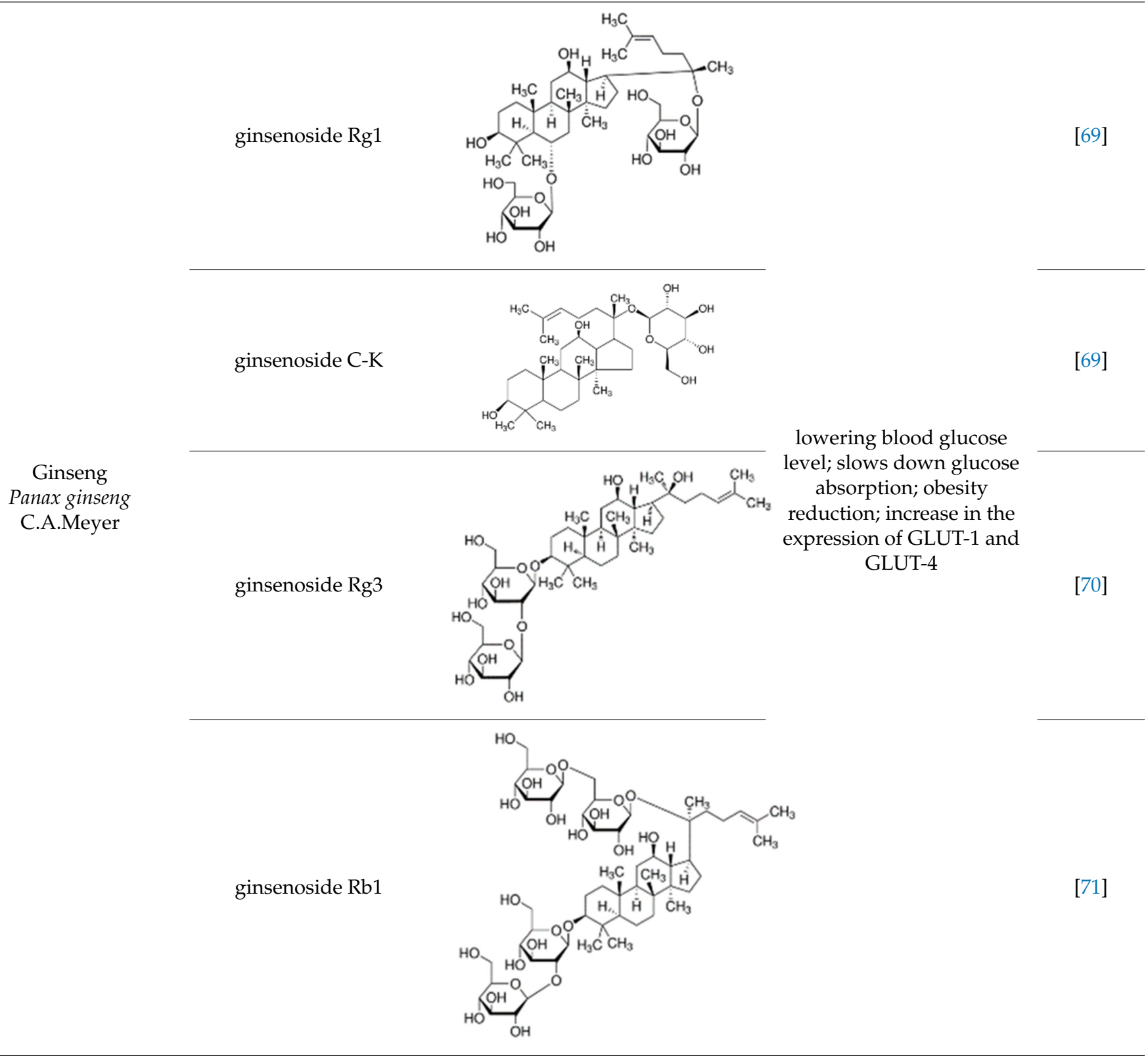

Source of chemical structures in this table: sigmaaldrich.com accessed on 13 December 2021 [72].

Numerous scientific reports have proven that chemical substances, including polyphenolic compounds, contained in white mulberry leaves demonstrate antiradical activity as well as chelating and reducing properties [11,25,73-75]. Thus, extracts of mulberry fruits may prevent liver cancer [76], and leaf extracts lower postprandial glucose [77] or are used in antidiabetic treatment [78,79] and show antibacterial activity [80]; white mulberry can inhibit atherosclerosis [81] due to its antioxidant activity [74,82]. In Chinese medicine, the brews are used in the treatment of colds, sore throats, and toothache and also in liver protection and for the purposes of lowering blood pressure [83,84]. Moreover, white mulberry extracts are used in the treatment of skin discoloration and its regeneration [85]. 
Antidiabetic activity is strongly related to the anti-obesity effect of Morus alba. There are preclinical studies that present the mechanisms responsible for the anti-obesity effects of white mulberry. They include:

- Inhibition of digestive enzymes, i.e., pancreatic lipase, cholesterol esterase [86], pancreatic $\alpha$-amylase (weak effect) [87], intestinal $\alpha$-glucosidase [74];

- $\quad$ Adipocyte differentiation [88,89];

- Influence on the appetite [90];

- Regulation of lipid metabolism: improvement of lipid profile [91,92];

- Improving the oxidative status of the organism [93-95].

At the same time, it is difficult to find clinical studies that undertake the issue of this relationship [89].

Mulberry leaves are considered an important raw material, having antidiabetic and hypoglycaemic activity $[53,96,97]$. This is related to the presence of alkaloids, including 1.5-dideoxy-1.5-imino-D-sorbitol (DNJ), terpenes, and steroids [53-55]. Morus alba has a natural flavonoid-morin-that is an activator and sensitizer of the insulin receptor stimulating the metabolic pathways [21]. Morin can also reduce endoplasmic reticulum stress (this factor, combined with hyperglycaemia, largely contributes to the pathogenesis of type 2 diabetes) in diabetic rats [56].

A study conducted on diabetic rats demonstrated that a 5-week-long administration of mulberry leaf extract reduced blood glucose levels by 5\% [19]. One of the substances responsible for such activity is DNJ, inhibiting $\alpha$-glucosidases, e.g., saccharase, isomaltase, maltase, and, primarily, glucoamylase; it is responsible for polysaccharides' decomposition to glucose, absorbed by the intestinal villi $[54,75]$. Moreover, white mulberry also belongs to the group of $\alpha$-amylase inhibitors [98].

Oral administration of mulberry leaf powder in humans in the amount of $0.8 \mathrm{~g}$ and $1.2 \mathrm{~g}$ considerably inhibited postprandial glycaemia and insulin secretion [99]. Therefore, mulberry leaves are used for Mon Tea-an antidiabetic tea prepared in Korea, Japan, and Chile [52]. Such teas and numerous pharmaceutical preparations with mulberry leaf extract additions are also common in Europe. Hansawasdi and Kawabata [100] reported that about $1 \mathrm{~g}$ of mulberry leaves is needed for the preparation of $100 \mathrm{~mL}$ of tea brewed in water of a temperature of $98^{\circ} \mathrm{C}$ for 3-5 min in order to inhibit $\alpha$-glucosidase activity. In a group of diabetic rats treated with polysaccharides isolated from Morus alba fruits for 7 weeks, reductions in the FBG, FSI, and oral glucose tolerance were observed compared to a group in which a diet without these polysaccharides was used. Additionally, polysaccharides from mulberry fruits used in the diet contributed to the improvement of pancreatic tissues in diabetic rats [101]. In turn, a study conducted on diabetic mice fed for only 28 days on a mixture of mulberry leaves and oat bran (6 g per $\mathrm{kg}$ of body weight; ratio 1:1) showed significantly higher hypoglycaemic activity (defined as lower levels of FBG and lower PPG $60 \mathrm{~min}$ in oral glucose tolerance tests) and more significant inhibition of aspartate transaminase and alanine transaminase activities compared to mice fed exclusively on mulberry leaves or exclusively on bran (in the same amount) [102].

Importantly, studies show that white mulberry leaves show no acute toxicity $\left(\mathrm{LD}_{50}>15.0 \mathrm{~g}\right.$ per kg of body weight), no subacute toxicity (NOAEL $=7.5 \mathrm{~g}$ per $\mathrm{kg}$ of body weight per day), and no genotoxicity, which makes them appear to be a safe food ingredient [103]. Currently, however, according to the EU novel food catalog, the only morphological element of white mulberry Morus alba recognized as a safe food ingredient in the European Union is its fruit (Table 2) [104]. 
Table 2. Medicinal plants status according to EFSA legislation [104].

\begin{tabular}{|c|c|c|}
\hline Medicinal Plant & $\begin{array}{l}\text { Morphological Element } \\
\text { Used in Folk Medicine }\end{array}$ & Registered as Novel Food \\
\hline \multirow{6}{*}{$\begin{array}{l}\text { Morus alba L. } \\
\text { White mulberry }\end{array}$} & fruits & NO \\
\hline & young leaves & $\begin{array}{c}\mathrm{N} / \mathrm{A} \\
\text { * but authorized in food supplement use }\end{array}$ \\
\hline & stems & $\begin{array}{c}\mathrm{N} / \mathrm{A} \\
\text { * but authorized in food supplement use }\end{array}$ \\
\hline & rhizome (root bark) & $\begin{array}{c}\mathrm{N} / \mathrm{A} \\
{ }^{*} \text { but authorized in food supplement use }\end{array}$ \\
\hline & root & $\mathrm{N} / \mathrm{A}$ \\
\hline & twigs & $\mathrm{N} / \mathrm{A}$ \\
\hline \multirow{2}{*}{$\begin{array}{c}\text { Trigonella } \\
\text { foenum-graecum L. } \\
\text { Fenugreek }\end{array}$} & seeds & $\mathrm{NO}$ \\
\hline & leaves & $\mathrm{N} / \mathrm{A}$ \\
\hline \multirow{4}{*}{$\begin{array}{l}\text { Cinnamomum zeylanicum J.Presl } \\
\text { Ceylon cinnamon }\end{array}$} & bark of the branches & $\mathrm{NO}$ \\
\hline & leaves & $\begin{array}{c}\text { NO } \\
\text { * only applies to food supplements }\end{array}$ \\
\hline & oil of the leaves & $\mathrm{N} / \mathrm{A}$ \\
\hline & flowers & $\mathrm{N} / \mathrm{A}$ \\
\hline \multirow{2}{*}{$\begin{array}{l}\text { Phaseolus vulgaris L. } \\
\text { Common bean }\end{array}$} & seeds & NO \\
\hline & pods & $\mathrm{NO}$ \\
\hline $\begin{array}{l}\text { Zingiber officinale Rosc. } \\
\text { Ginger }\end{array}$ & rhizome & $\mathrm{NO}$ \\
\hline \multirow{4}{*}{$\begin{array}{l}\text { Panax ginseng C.A.Meyer } \\
\text { Ginseng }\end{array}$} & root & $\mathrm{NO}$ \\
\hline & berries & NO \\
\hline & leaves & $\mathrm{NO}$ \\
\hline & oil & $\mathrm{NO}$ \\
\hline
\end{tabular}

YES - element has not been used as food in European Union before 15 May 1997 and has a safety assessment status; NO-element has been used as food in European Union before 15 May 1997 and does not need safety assessment; N/A—there was no request or a request has not been processed yet; * — exceptions.

\subsection{Fenugreek (Trigonella foenum-graecum L.)}

Fenugreek is an annual herbal plant with fine seeds from the Leguminosae family. In its natural state, fenugreek is found in the Mediterranean area as well as in India and China. It is cultivated mainly as a forage plant. Both the seeds and leaves of fenugreek appear in literature as an ingredient of food and as medicine [105].

The high levels of protein, vitamins, and mineral compounds mean that germinated fenugreek seeds are a valuable component of a so-called healthy diet. The seeds of fenugreek contain mucous polysaccharides-galactomannans (25-45\%), proteins ( $43.8 \%$; mainly tryptophan and lysine), free amino acids (mainly 4-hydroxyisoleucine and histidine) [106], fats (7.9\%) [107], steroid saponins, alkaloid—trigonelline, coumarins, flavonoids, sterols, lecithin, and choline as well as nicotinic acid (formed from the breakdown of trigonelline during roasting) and minerals [108]. Fenugreek leaves are a source of $\beta$-carotene $(0.019 \%)$, ascorbate $(0.22 \%)$, iron, calcium, and zinc [106]. In the group of fenugreek polyphenol compounds, rhaponticin and isovitexin are believed to be the most bioactive [109].

The presence of these compounds and their interaction have a positive effect on the course of many diseases and help to protect against their occurrence. Both in vitro and in vivo studies have been conducted on the therapeutic or prophylactic role of fenugreek.

Nutraceutical properties of fenugreek include, i.a., blood purification; sweat-inducing effects, supporting the removal of toxins; cleaning the lymphatic system; maintaining mu- 
cous membranes in good condition; removing excess mucus from the throat; relieving colds, bronchial problems, flu, asthma, rhinitis, constipation, sinusitis, pneumonia, and laryngitis [105]. The use of fenugreek seeds in supporting the treatment of neurodegenerative diseases such as Parkinson's disease has also been analyzed [110].

With respect to the gastrointestinal tract, it was observed that dried or germinated fenugreek seeds, or a pap made of them, stimulate appetite and digestion and are used in alimentary tract disorders: dyspepsia, tympanites, gastritis, and liver diseases. They are also used as a raw material with expectorant activity in upper respiratory tract diseases. In traditional medicine, hot compresses made from fenugreek seeds (cataplasms) are used in the treatment of local inflammatory conditions of the skin and subcutaneous tissue, e.g., furuncles, abscesses, and ulcerations [111].

Trigonella foenum-graecum is a valuable raw material in the regulation of the lipid profile. In studies [112] with Wistar rats with obesity induced by a high-fat diet, reduction in body weight gain, body mass index, blood glucose, white adipose tissue weights, and serum insulin were observed. In clinical studies, a 30-day administration of $25 \mathrm{mg}$ of fenugreek seed powder solution significantly helped in the area of dyslipidemia in newly diagnosed type 2 diabetic patients [1].

Fenugreek has antioxidant properties, resulting from the presence of, i.a., gallic acid, protocatechuic acid, catechin, gentisic acid, chlorogenic acid, and vanillic acid [106]. In a DPPH radical test, the value of $\mathrm{IC}_{50}$ for a Trigonella foenum-graecum seed methanol extract was determined at $350 \mu \mathrm{g} / \mathrm{mL}$, while in a ABTS IC $_{50}$ cation radical test, it was $117 \mu \mathrm{g} / \mathrm{mL}$ [113].

Fenugreek is considered to be one of the Indian plant species exhibiting antidiabetic activity $[21,24,59]$. The hypoglycaemic or antidiabetic activities of fenugreek leaves have been the subject of many studies. The most common compounds of fenugreek identified as probably antidiabetic are shown in Table 1.

The antiglycaemic activity of fenugreek probably results from the synergistic activity of various chemical compounds. Some research explains that the presence of galactomannans means that consumption of fenugreek seeds in the form of pap delays stomach emptying, moderates carbohydrate absorption, and inhibits glucose transport [57]. It has been proposed that the mucilage contained in the raw material covers the intestine diffusion layer and thus retards nutrient absorption, including carbohydrates [114]. It has also been demonstrated that an effect of Trigonella foenum-graecum extract activity involves an increase in the amount of erythrocyte insulin receptors and thus peripheral glucose consumption [57]. Hypoglycaemic activity may be related to the normalization of gluconeogenic enzymes and a decrease in glycolytic enzyme activity [111]. In turn, Broca et al. [58] conducted a study on rats with induced diabetes and demonstrated that 4-hydroxyisoleucine was the active component causing the hyperglycaemia reduction. In this study, the administration of 4-hydroxyisoleucine to sick animals for 6 days resulted in a glycaemia reduction from 163.5 to $143.6 \mathrm{mg} / \mathrm{dL}$ [58]. This amino acid has been identified as the main active component of fenugreek seeds by many other researchers [115]. 4-Hydroxyisoleucine inhibits insulin secretion in a wide concentration range, which contributes to a decrease in blood glucose levels. Apart from lowering glucose levels, fenugreek seeds also cause a reduction in TC [114].

There are also some reports suggesting that the hypoglycaemic properties of Trigonella foenum-graecum result from its high content of dietary fiber (up to as much as $30 \%$ ), especially its insoluble fraction [116]. Steroid saponins from Trigonella are also indicated as bioactive compounds responsible for the antidiabetic effect of this spice [59], and their amount shows wide variability among the fenugreek genotypes [117].

In rats with induced diabetes, it was observed that consumption of ethanolic fenugreek seed extract ( 0.25 and $0.5 \mathrm{~g}$ per $\mathrm{kg}$ of body weight) for 14 days significantly reduced serum glucose compared to the control group. The level of changes was very similar to that caused by glibenclamide-a drug used for the purposes of attenuation of serum parameters in diabetics [118]. 
The antidiabetic potential of fenugreek seeds extract was analyzed in a 4-week study with streptozocin-induced diabetic Sprague-Dawley rats. The dose of $100 \mathrm{mg}$ per $\mathrm{kg}$ of body weight significantly reduced blood glucose, reduced levels of liver enzymes (aspartate aminotransferase and alanine aminotransferase), and reduced triglycerides. Moreover, mild protection of hepatic, renal, and pancreatic tissues after fenugreek administration was observed [20].

In clinical trials, on the other hand, consumption of Trigonella seed extract, enriched in $40 \%$ of furostanolic saponins for 30,60 , and 90 days, resulted in a $6.69 \%, 10.31 \%$, and $21.98 \%$ reduction of FBG, respectively, a $13.7 \%, 20.6 \%$, and $30.4 \%$ reduction in postprandial blood glucose levels, and a reduction in glycosylated hemoglobin levels (but not significant) [119]. In studies by Singh et al. [120], 20 patients with type 2 diabetes took $5 \mathrm{mg}$ of glipizide per day (Group A) for 12 weeks, 20 patients took $500 \mathrm{mg}$ of fenugreek seed extract twice a day (Group B), and 20 patients took $2.5 \mathrm{mg}$ of glipizide $+500 \mathrm{mg}$ of fenugreek seed extract per day (Group C). In all groups, a significant decrease in FBG (A-33.97\% > C-29.96\% > B-24.62\%) and glycated hemoglobin (A-12.98\% > C-10.62\% > B-9.38\%) was observed; in Groups B and $\mathrm{C}$, a significant decrease in TC (respectively: $-5.66 \%$ and $-3.87 \%$ ), plasma triglycerides $(-17.23 \%$ and $-11.34 \%$, respectively) and LDL cholesterol $(-4.15 \%$ and $-2.68 \%$, respectively) could be noted. On this basis, it was concluded that fenugreek therapy (alone or in combination with drugs) significantly improved glycaemic and dyslipidemic control.

In terms of inhibition of pancreatic lipase, the ethanol extracts of fenugreek compared to the ethanol extracts of quinoa showed 10-fold higher inhibitory activity. In turn, the levels of $\alpha$-amylase inhibition by these two raw materials were significantly lower than those obtained in tests with pancreatic lipase and were similar to each other-mild inhibition (24.8\% for quinoa and $27.3 \%$ for fenugreek concentrated extracts) [41].

Fenugreek allergenicity analyses, including the level of specific IgE antibodies, have shown that fenugreek has many potential allergens and a high level of cross-reactivity with peanuts [121]. Moreover, this plant has a probable teratogenic and abortive effect and changes hematology and blood biochemistry [122]. According to EFSA, only for fenugreek seeds, a safety assessment is not required (Table 2) [104].

\subsection{Ceylon cinnamon (Cinnamomum zeylanicum J.Presl)}

Ceylon cinnamon belongs to the Lauraceae family; it originates from Ceylon but is cultivated in various regions of southern Asia and North America. The raw material is bark (Cinnamomi cortex) without the internal layer, the so-called primary bark. Ceylon cinnamon bark contains $0.5 \%$ to $4.0 \%$ oil, depending on the origin of the raw material. The main components of the oils are as follows: cinnamaldehyde (65-75\%), cinnamyl acetate and eugenol (ca. $5 \%$ in total), and $\beta$-caryophyllene (up to $4 \%$ ). Moreover, the bark contains polysaccharides (mucilage), phenolic acids (cinnamic acid and its derivatives), oligomeric proanthocyanidins, diterpenes, and others [123].

For centuries, cinnamon has been used in Chinese homes as a spice and also as a traditional Chinese remedy for cold and flu [124]. Historically, it has also been known for its antibacterial, antifungal, and carminative properties [125,126].

The antioxidative and antibacterial activity of an extract derived from cinnamon has been demonstrated in recent years [127]. Among the best-known herbs and spices in terms of antioxidant content, researchers indicate that cinnamon ( $77 \mathrm{mM}$ per $100 \mathrm{~g}$ of antioxidant) has less antioxidative properties than only several other plants, which include allspice, cloves, and peppermint [63]. Ethanol extracts from cinnamon bark in the ABTS cationic radical test reached the value of $525.85 \mu \mathrm{M}$ Trolox equivalent per $\mathrm{g}$ of dry weight, $87.45 \%$-in the DPPH radical test, and $637.00 \mu \mathrm{M}$ Trolox equivalent per $g$ of dry weight in the FRAP test [128]. This is important in reducing the oxidative stress of patients.

Studies have also demonstrated that cinnamon bark in doses of 1-6 g per day causes a reduction in TG, TC, and LDL fraction in patients with type 2 diabetes [63]. This is probably caused by the presence of a methylhydroxychalcone polymer (MHCP) stimulating, almost like insulin, glucose uptake by adipocytes [61]. In the study by Jarvill-Taylor et al. [61], 
MHCP activated insulin receptor autophosphorylation and, thus, glucose uptake and glycogen synthesis. Thus, a synergism between MHCP and insulin was observed since the concurrent application of both substances induced a considerably better response than the sum of responses resulting from their separate application. Another study [62] conducted on rats suggested the significant importance of cinnamaldehyde in antiglycaemic and antilipemic activity.

Antidiabetic activity was analyzed in the studies on diabetic rats [129]. It was observed that administering $200 \mathrm{mg}$ of ethanolic extract of Cinnamomum zeylanicum per $\mathrm{kg}$ of body weight to animals once a week for 4 weeks had a hypoglycaemic effect. In this study [129], blood glucose (from 257.0 to $122.9 \mathrm{mg} / \mathrm{dL}$ after 4 weeks) and glycosylated hemoglobin levels were reduced.

Mirfeizi et al. [130] noted in a randomized controlled trial that the introduction of cinnamon into the diet of patients with type 2 diabetes mellitus, in a glucose load test, reduced the glycaemia after $90 \mathrm{~min}$ to $224 \mathrm{mg} / \mathrm{dL}$, while without the use of cinnamon in the same patients, the glycaemia after $90 \mathrm{~min}$ was $270 \mathrm{mg} / \mathrm{dL}$. On the other hand, Vafa et al. [131] observed, by administering $3000 \mathrm{mg}$ of cinnamon powder daily for 8 weeks to 44 patients, a reduction in insulin serum levels by $12.87 \mathrm{mIU} / \mathrm{dm}^{3}$ and a reduction in FBG by $0.45 \mathrm{mg} / \mathrm{dL}$.

Santos and Silva [63] indicate six pathways improving serum parameters and fat loss:

1. Cinnamon fiber delays the emptying of the stomach;

2. Eugenol from cinnamon acts as an inhibitor of $\alpha$-glucosidase in the intestines;

3. In the myocyte, there is an improvement of insulin receptor phosphorylation, synthesis, and translocation of GLUT-4 to glucose uptake and, therefore, an increase of glycogen;

4. Cinnamaldehyde provides sympathetic actions; increased noradrenaline may increase the heart rate and thermogenic influence on brown adipose tissue;

5. The proposed mechanism of body fat loss across cinnamon intake occurs from the $\mathrm{UCP} 1$ activation in the mitochondria of brown adipose tissue and greater PPAR- $\alpha$ expression in white adipose tissue and, consequently, increases $\beta$-oxidation by means of enzymatic action of acyl-CoA oxidase;

6. Expected improvement of glycaemic, lipid, and antioxidant parameters.

Moreover, according to the research, bioactive compounds from Ceylon cinnamon show potentially beneficial activity in the treatment of cancer [132], inflammation, immunomodulatory diseases [133], and wound healing [134]. Ceylon cinnamon supplementation decreased the blood pressure of diabetes patients in clinical trials while not affecting body weight, body mass index, and waist circumference [135]. Cinnamaldehyde, found in cinnamon, has been indicated as promising and safe for the treatment or prevention of Alzheimer's disease [123].

Due to positive premises from experimental studies, cinnamon application as a factor adjunctive to carbohydrate metabolism also seems to be an interesting alternative in functional food supporting the treatment of diabetes.

According to the EFSA, Cinnamomum zeylanicum bark of the branches is used as food and leaves are used as food supplements in Europe. A request for the oil of the leaves is being processed (Table 2) [104].

\subsection{Ginger (Zingiber officinale Rosc.)}

Ginger is one of the oldest spice and medicinal plants [136]. Common ginger, which belongs to the Zingiberaceae family, is a herbaceous plant with a strong rhizome divided into tuberous sections. It has sterile shoots up to $1.5 \mathrm{~m}$, with evenly narrow lanceolate leaves $5-30 \mathrm{~cm}$ long and $8-20 \mathrm{~cm}$ wide. It probably originated in Southeast Asia, and it is cultivated in many tropical regions, including Africa, China, India, and Jamaica [67]. In Europe, ginger is very widespread and is often used in combination with Far East cuisine.

Ginger is rich in essential oils, the amount of which, in the rhizome, ranges from $1 \%$ to $3 \%$. Among more than 50 identified essential oils, the ones to be mentioned in 
particular are monoterpenes (felandrene, camphene, 1,8-cineol, geranial, citral, terpineol, borneol) and sesquiterpenes (ar-curcumen and $\alpha$-zingiberene 30-70\%, $\beta$-sesquifelandrene $15-20 \%$, $\beta$-bisabolene $10-15 \%$, zingiberol). Gingerols are responsible for the spiciness of fresh ginger, while their dehydrated forms, shoagols, are responsible for the spiciness of dried ginger. In addition, ginger also contains diarylheptones, diterpenes, and monoacyldigalactosylglycerols [65]. Due to the popularity of the plant in nutrition, special attention is paid to the variability of biologically active compounds in ginger as a result of drying. Freeze-dried and infrared and intermittent microwave-convection drying material has better antioxidant properties, higher retention of gingerols, phenolics, and flavonoids than air-dried $\left(60^{\circ} \mathrm{C}\right)$ or microwave-dried slices of ginger [137].

In the past, in traditional medicine, ginger was used as an ingredient with carminative, expectorant, and astringency properties [138]. The studies conducted so far indicate that the beneficial qualities of ginger rhizomes are due to, among other things, its hypoglycaemic, hypocholesterolemic, antiarthritic, antirheumatic, and antioxidant activity [139-142]. The use of ginger extracts reduced a high level of TC in rabbits who were on a 10-week high-fat diet, proving the antihyperlipidemic properties of ginger [143]. Ginger is also known for its analgesic and anti-inflammatory qualities, which is evidenced by its inhibitory effect on prostaglandin synthesis. It was also demonstrated that ginger contains components with pharmacological properties that imitate anti-inflammatory drugs. In in vitro studies, aqueous extracts had a greater inhibitory effect on lipoxygenase than diclofenac (58\% vs. $52 \%)$, while in in vivo models, they beneficially reduced edemas in rats and demonstrated identical effects to indomethacin (a strong anti-inflammatory and analgesic agent) in the reduction of NOx. The most potent active compounds were 6-paradol, 6-shogaol, and 1-dehydro-6-gingerol [66]. The effects of ginger essential oils, in the amount of $28 \mathrm{mg}$ per $\mathrm{kg}$ per day, prevented chronic arthritis, comparable to $17-\beta$-estradiol, in an animal model [144]. Jafarzadeh and Nemati [145] identified many possible mechanisms of action of ginger active ingredients with immunomodulatory, anti-inflammatory, and antioxidative potential in the context of multiple sclerosis treatment. On the other hand, ginger protects tissues from radiation [146] and shows chemopreventive effects against some skin and breast cancer [147]. In Middle Europe, many people use ginger during the fall and winter season as an important element of their diet to prevent infections and to treat upper respiratory tract infections.

Ginger has an antidiabetic effect, which was demonstrated in several studies on different models. Conducting studies on rats with induced diabetes, feeding them with ginger extract in the amount of $4 \mathrm{~mL}$ per $\mathrm{kg}$ of body mass pr day per 6 weeks significantly reduced blood glucose compared to sick animals. It concerned animals fed with ginger, both before and after inducing diabetes $[65,141]$. The consumption of ginger juice in the amount of $4 \mathrm{~mL}$ per $\mathrm{kg}$ per day for 6 weeks flattened the blood glucose and insulinemia curve in the glucose tolerance test in the group of diabetic rats [148]. Aqueous ginger extract (in the amount of $100-500 \mathrm{mg}$ per $\mathrm{kg}$ ) administered daily for 30 days to rats increased the activity of glycolytic enzymes and had an antihyperglycaemic effect [149]. Ethanolic ginger extract included in an animal diet in the amount of $200 \mathrm{mg}$ per $\mathrm{kg}$ for 30 days reversed hyperglycaemia and improved the activities of extra- and intra-mitochondrial enzymes, resulting in a nephroprotective effect [150]. Ginger increases insulin sensitivity, protects pancreatic $\beta$-cells, and reduces oxidative stress in rodents [151]. Model studies in L6 mouse myoblast and myotubes showed that the main components responsible for the antidiabetic potential of ginger are shoagol and gingerol [152,153].

Clinical research has confirmed the antidiabetic properties of ginger. In a group of newly diagnosed obese $\left(\mathrm{BMI}>30 \mathrm{~kg} / \mathrm{m}^{2}\right)$ patients with diabetes, El Gayar's team [154] showed that daily consumption of 3 capsules, each containing $600 \mathrm{mg}$ of ginger (dried rhizome) powder for 8 weeks, resulted in a significant $(p<0.001)$ reduction in BMI $\left(-0.54 \mathrm{~kg} / \mathrm{m}^{2}\right)$, $\mathrm{HbA}_{1 \mathrm{c}}(-1.11 \%)$, FBG $(-51.15 \mathrm{mg} / \mathrm{dL})$, FSI $(-7.88 \mathrm{mIU} / \mathrm{L}), \mathrm{TC}(-31.10 \mathrm{mg} / \mathrm{dL})$, and LDL cholesterol (-17.70 mg/dL). In Khandouzi's study [155], consumption of a slightly higher dose of ginger powder ( $2 \mathrm{~g}$ per day for 12 weeks) had similar effects (FBG: $-19.41 \mathrm{mg} / \mathrm{dL}$; 
$\mathrm{HbA}_{1 \mathrm{c}}$ : $-0.77 \%$; apolipoprotein $\mathrm{B}:-12.45 \mathrm{mg} / \mathrm{dL}$ ). Iranian patients with type 2 diabetes who consumed $3 \mathrm{~g}$ of ginger powder in the form of capsules showed a significant improvement in diabetic parameters (serum glucose: $-19.41 \mathrm{mg} / \mathrm{dL} ; \mathrm{HbA}_{1 \mathrm{c}}$ : $-0.77 \%$; $\mathrm{SI}$ : $-1.46 \mu \mathrm{IU} / \mathrm{mL}$; insulin resistance: -16.38 ; high-sensitive CRP: $-2.78 \mathrm{mg} / \mathrm{dL}$ ) compared to the control group of patients [156]. On the other hand, in another group of patients with diabetes mellitus, ginger powder added to the diet in the amount of $3 \mathrm{~g}$ per day decreased only the SI but did not affect $\mathrm{FBG}$ and $\mathrm{HbA}_{1 \mathrm{c}}$ [157].

The ways in which the active ingredients in ginger affect glycaemic control are shown in the diagram (Figure 1).

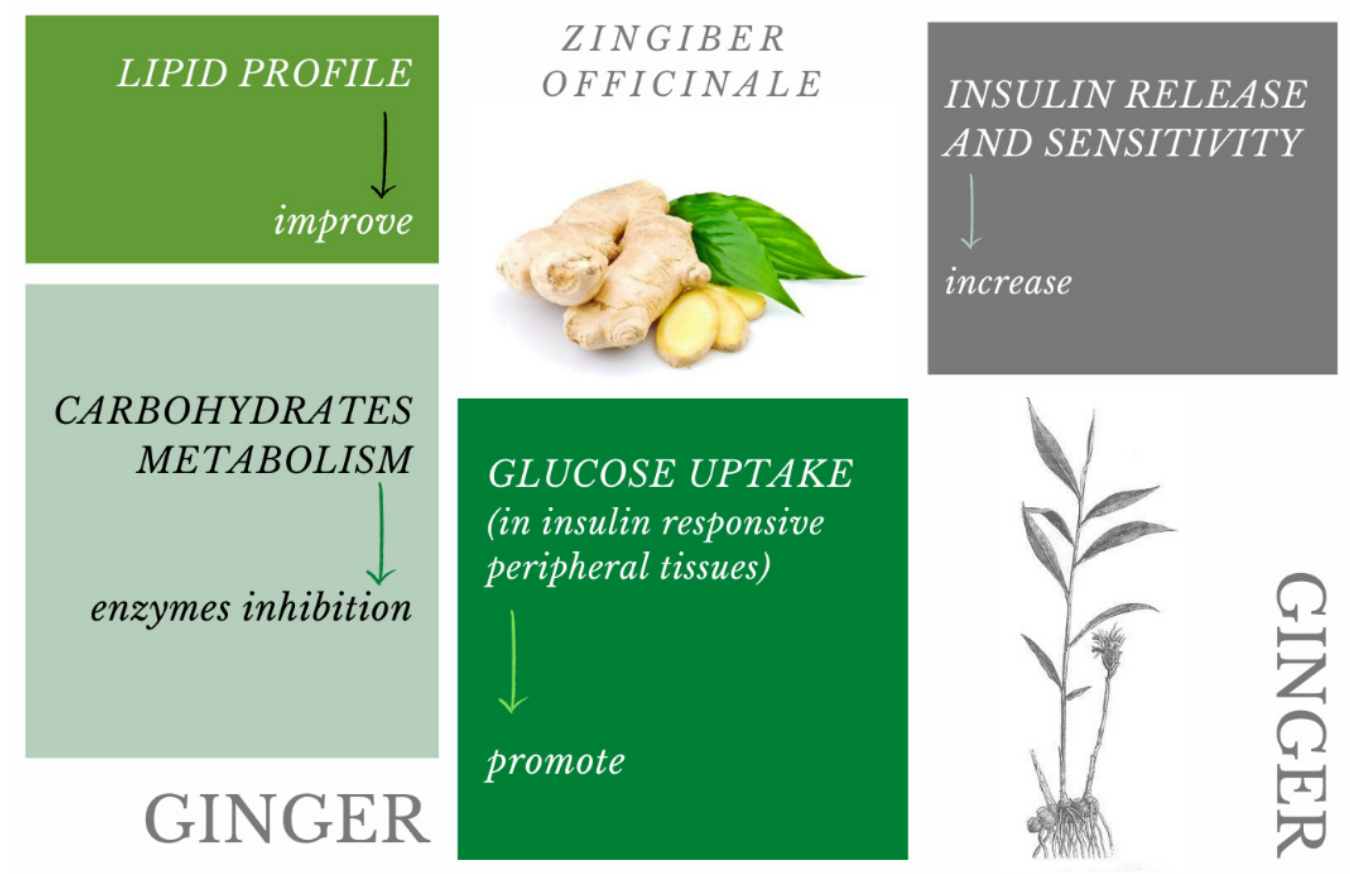

Figure 1. The ways in which the active ingredients in ginger affect glycaemic control [158].

Due to its properties, ginger can be used in the production of medicinal functional food because of its effectiveness and non-toxicity [139]. The FDA approved ginger as 'GRAS' plant material at a dosage of $<4 \mathrm{~g}$ per day. However, at doses of $>6 \mathrm{~g}$ of ginger per day, researchers reported some side effects (heartburn, mild diarrhea, abdominal discomfort) [147]. In Europe, ginger is highly trusted by consumers and is easily accessible on the market.

\subsection{Common Bean (Phasolus vulgaris L.)}

Common bean is a member of the Fabaceae bean family, and the pericarp of Phaseoli pericarpium is a medicinal raw material. Common bean originated from Europe and Western Asia, and it is widely cultivated in North America, mostly because of its culinary value [159].

The nutritional value of bean seeds is due to their high content of protein, starch, B vitamins, and minerals. Important non-nutritional components of bean seeds are polyphenolic compounds, which are most responsible for the antioxidant properties of those raw materials [160,161]. Beans are among the most popular leguminous plants grown for food purposes in Poland and other countries. The usable parts of the bean are the unripe pods, called string beans, and the dry ripe seeds.

In addition to hypoglycaemic compounds such as guanidine derivatives (amino- $\beta$ guanidino-isovaleric acid), phaseoloside, and chromium salts, common bean also contains amino acids, choline, trigonelline, allantoin, pipecolinic and traumatic acid, and 
flavonoids [161,162]. The main activity of the bean pericarp is its diuretic effect and protecting effect in the case of kidney dysfunction resulting from hyperglycaemia [163].

The antidiabetic activity of beans has been demonstrated in animal studies. As a result of feeding rats with induced diabetes with a bean extract (200 mg per kg, 28 days), an increase in the ability of GLUT- 4 to regulate glucose utilization (increase in GLUT-4 content in skeletal muscle) was observed [164]. In the group of streptozotocin-induced diabetic rats with a diet enriched with cooked common bean $(100 \mathrm{mg} / \mathrm{kg})$, FBG was reduced by $25 \%$ after 2 weeks and by 35\% after 4 weeks [163]. Aqueous bean extract administered to animals for 40 days in slightly higher amounts (100 mg and $200 \mathrm{mg}$ per $\mathrm{kg}$ ) had similar effects (FBG $-25 \%$ and $-50 \%$, respectively) and resulted in a significant reduction of TC and TG, while in the amount of $200 \mathrm{mg}$ per $\mathrm{kg}$, the extract produced similar medicinal effects to glibenclamide [165]. Studies conducted simultaneously on healthy and sick rats showed that the introduction of bean $(300 \mathrm{~g} \mathrm{per} \mathrm{kg}$ ) into the diet of animals treated with glibenclamide undoubtedly reduced the dose of the drug necessary to improve glycaemia [166]. In addition, common bean extract inhibited the adipogenesis of 3T3-L1 adipocytes and reduced the lipid content in adipocytes $(-20.71 \%)$ in vitro [167].

The knowledge acquired so far on the properties of common bean may be helpful in the treatment of diabetes, especially in kidney inflammation and other nephropathies that may be a consequence of hyperglycaemia.

\subsection{Ginseng (Panax ginseng C.A.Meyer)}

The root of this relict perennial from the Araliaceae family has been known in medicine for centuries. The description of its qualities can be found in the famous, ancient book of medicines "Shennong bencao" (XI century BC), but in Europe, it first appeared on the table of King Louis XIV [168]. The name ginseng stems from the shape that the root takes, i.e., the human body [169]. The raw material is dried roots collected in autumn from 4- to 6-year-old plants, with a minimum diameter of about $2 \mathrm{~cm}$. Ginseng is found throughout China, from the slopes of the central Himalayas, through Korea and Japan, and to North America [170].

The main chemical components of this raw material include triterpene saponins (2-3\%), panaxosides, and ginsenosides, which increase the mental and physical efficiency of the body and have an antistress effect. This raw material also contains polysaccharides, peptidoglycans (panaxans A-U), polyacetylenes, essential oil, sesquiterpene alcohols, sterols, flavonols, and phenolacids. Moreover, the activity of wild-growing ginseng is higher than plantation ginseng [171-173].

In Asian culture, ginseng has been used for centuries to reduce fatigue and mental weakness, to treat decreased libido, in stomach ulcers, in insomnia, to promote longevity, and to increase intelligence, as well as to improve eyesight, spleen function, and appetite [170,174-176]. Other possible uses of ginseng were also considered [177].

Currently, clinical studies have demonstrated that Panax ginseng root has extended preventive or even curative effects, protecting against cancer and nephropathy. Moreover, it improves blood circulation as well as protects against illnesses of the respiratory and nervous systems. It also improves liver activity, physical endurance, and bone metabolism and ensures the neutralization of changes in postmenopausal osteoporosis [178-185]. It is generally believed that ginseng improves metabolism and, thus, helps to improve and maintain good health, and, for this reason, it is an ingredient of dietary supplements [186].

Korean clinical research on a group of 72 patients with diabetes showed that consumption of a vinegar extract of Panax ginseng for 8 weeks at doses of 1500-3000 mg daily resulted in a notable reduction of $\mathrm{HbA}_{1 \mathrm{c}}$ (from $-0.56 \%$ to $-0.29 \%$ ) and FBG (from -21.4 to $-6.76 \mathrm{mg} / \mathrm{dL}$ ) compared to the placebo group [187]. Additionally, the consumption of 2 capsules containing 30\% of hydrolyzed ginseng extract daily for 8 weeks in the case of 23 diabetic patients resulted in a significant reduction of FBG and $\mathrm{PPG}_{60 \mathrm{~min}}$, as well as a visible, but not statistically significant, reduction of $P_{P G} 3 \mathrm{~min}$. The authors of the study concluded that ginseng slows down glucose absorption in the bowel or increases 
glucose intolerance at the stage of absorption [188]. Since CK and Rg1 ginsenosides increase glucose uptake in 3T3-L1 adipocytes with insulin [69], such an effect is possible. On the contrary, fermented ginseng in the amount of $2.7 \mathrm{~g}$ per day in the group of 40 people reduced $\mathrm{PPG}_{120 \mathrm{~min}}$ (by $17.2 \%$ ) and flattened the glucose curve (by $27.4 \%$ ), with no effect on fasting glycaemia and insulinemia. The fermentation process applied could certainly improve the bioavailability of ginsenosides from the raw material, but the time of nutritional exposure was shorter than in other clinical studies [189]. On the other hand, in the group of 68 non-diabetic patients, consumption of $6 \mathrm{~g}$ of ginseng for 12 weeks did not affect insulin and insulinemia sensitivity [190]. Additionally, a shorter, 8-week introduction of ginseng ( 6 g per day) to the diet of obese women (50 individuals) reduced their obesity levels, regardless of the treatment used [191].

The effect of ginseng on the change and/or improvement of biochemical parameters in diabetic patients may be related to the interaction of several major bioactive compounds. Studies on mice on a high-fat diet showed that $\mathrm{Rb} 1$ ginsenoside weakens the symptoms of low insulin sensitivity and high glycaemia [192]. In the animals with induced diabetes, Rb1 also improves the lipid profile and lowers glycaemia and insulin sensitivity, becoming of interest for patients with coexisting liver disease [71]. On the other hand, Rg3 ginsenoside, formed by thermal degradation of other ginsenosides (e.g., during the production of red or black ginseng), shows the highest glucagon-like peptide- 1 secretion from 15 ginsenosides analyzed by Kim's team [70]. An increase in the expression of GLUT-1 and GLUT-4, which results in a greater uptake of glucose, has also been suggested as a possible factor in the therapeutic effects of ginseng against diabetes [193,194].

In Europe, ginseng is an available and well-known ingredient. It usually appears in a dried form, extracts, or dietary supplements [195]. According to EFSA, Panax ginseng was used as the food of food ingredient before the year 1997; thus, it is not a novel food product [104] (Table 2).

\section{Conclusions and Future Perspectives}

Because of their antidiabetic properties, various morphological elements of the abovedescribed plants - mulberry, fenugreek, cinnamon, common bean, ginger, and ginsengmay be used as medicinal agents (Table 3). They can be administered to people in a variety of forms: basic, crushed, slightly processed, or as an ingredient of functional food. The status of these plants is described as non-toxic to the average patient, allowing them to be used as a substitute for conventional pharmacology. The antidiabetic properties of the analyzed plants have been confirmed by numerous in vitro tests and many preclinical in vivo studies published. Even though the results of the published papers are very favorable, the number of clinical trials is still disappointing. Increasing clinical trials, with the use of larger populations, is recommended. Moreover, there is a small number of trials considering mixed therapies (drugs and plant pharmaceuticals of natural origin). Plant-based diets are becoming more popular with the next generation of Europeans, also due to the ecological aspects. For this reason, future outcomes of clinical trials should indicate the optimal methods of introducing medicinal plants into the pharmacological treatment of diabetes mellitus and the optimization of doses and forms of plants in mixed therapies in order to avoid undesirable side effects. Simultaneously, the safety of the proposed therapies should be analyzed. The literature data also highlight many other activities of these plants, and the impact of bioactive compounds contained in them can be described as multi-fold. 
Table 3. Some studies considering medicinal plants, as described in this mini review.

\begin{tabular}{|c|c|c|c|}
\hline Medicinal Plants & $\begin{array}{l}\text { Effective Dose, Intake Duration, } \\
\text { and Form of Plant Material }\end{array}$ & $\begin{array}{c}\text { Effects of Consumption in In Vivo Models } \\
\text { (Level of Change) }\end{array}$ & Source \\
\hline \multirow{9}{*}{$\begin{array}{l}\text { Morus alba L. } \\
\text { White mulberry }\end{array}$} & $20 \mathrm{mg} / 100 \mathrm{~g}$ b.w./d I $5 \mathrm{w}$ | leaf extract & R: FBG reduction $(5 \%)$ & [19] \\
\hline & $\begin{array}{c}0.8 \mathrm{~g} \text { and } 1.2 \mathrm{~g} \mid \text { single dose } \mid \text { leaf } \\
\text { powder enriched with DNJ }(1.5 \%)\end{array}$ & $\begin{array}{c}\mathrm{H}: \mathrm{PPG}_{60 \mathrm{~min}}, \mathrm{PPG}_{90 \mathrm{~min}} \text { inhibition, insulin } \\
\text { secretion inhibition }\end{array}$ & [99] \\
\hline & $100 \mathrm{~mL}$ ( $1 \mathrm{~g}$ of leaves $)$ | tea & R: inhibition of $\alpha$ - glucosidase activity & [100] \\
\hline & $\begin{array}{l}400 \mathrm{mg} / \mathrm{kg} \mathrm{b} . \mathrm{w} .|7 \mathrm{w}| \text { fruits } \\
\text { (polysaccharides) }\end{array}$ & $\begin{array}{c}\text { R: FBG reduction (31.9-47.5\%), FSI reduction } \\
(3.41-4.19 \mathrm{mIU} / \mathrm{L}), \text { OGTT reduction } \\
(18.12-19.30)\end{array}$ & [101] \\
\hline & $\begin{array}{c}6 \mathrm{~g} / \mathrm{kg} \text { b.w. I } 28 \mathrm{~d} \text { I leaves with oat } \\
\text { bran (1:1) }\end{array}$ & $\begin{array}{c}\text { M: FBG reduction, } \mathrm{PPG}_{60 \mathrm{~min}} \text { reduction, aspartate } \\
\text { transaminase inhibition, alanine } \\
\text { transaminase inhibition }\end{array}$ & [102] \\
\hline & $\begin{array}{l}20 \mathrm{mg} \text { and } 40 \mathrm{mg} \text { and } 80 \mathrm{mg} / \mathrm{kg} \mid 4 \\
\mathrm{w} / \mathrm{DNJ} \text { extracted from leaves }\end{array}$ & $\begin{array}{l}\text { M: BG reduction, b.w. reduction, SI reduction, } \\
\text { HOMA-IR index reduction }\end{array}$ & [55] \\
\hline & $\begin{array}{l}30 \mathrm{mg} / \mathrm{kg} \mathrm{b.w.}|4 \mathrm{w}| \text { morin } \\
\text { from leaves }\end{array}$ & $\begin{array}{c}\text { R: downregulation of PERK-eIF2 } \alpha \text {-ATF4 } \\
\text { pathway, BG reduction }(69.42 \%)\end{array}$ & [56] \\
\hline & $\begin{array}{l}600 \mathrm{mg} / \mathrm{kg} \text { b.w. } / \mathrm{d} \mid 6 \mathrm{w} / \text { ethanolic } \\
\text { leaf extract or leaf powder }\end{array}$ & $\begin{array}{l}\text { R: FBG reduction, TC reduction, TG reduction, } \\
\text { LDL reduction; leaf powder more effective than } \\
\text { leaf extract }\end{array}$ & [91] \\
\hline & $2 \mathrm{~g} / \mathrm{kg}$ b.w. $/ \mathrm{d}|4 \mathrm{w}|$ leaf extract & $\begin{array}{l}\text { R: FBG reduction, OGTT reduction, HOMA-IR } \\
\text { reduction, TC reduction, TG reduction, LDL } \\
\text { reduction, insulin resistance improved }\end{array}$ & [97] \\
\hline \multirow{6}{*}{$\begin{array}{l}\text { Trigonella } \\
\text { foenum-graecum L. } \\
\text { Fenugreek }\end{array}$} & $50 \mathrm{mg} / \mathrm{d} / 30 \mathrm{~d}$ I seed powder solution & $\begin{array}{l}\text { H: TC reduction }(13.6 \%) \text {, TG reduction }(23,53 \%), \\
\text { LDL reduction }(23,4 \%) \text {, HDL improved }(21.7 \%)\end{array}$ & [1] \\
\hline & $\begin{array}{l}50 \mathrm{mg} / \mathrm{kg} \text { b.w./d } 16 \\
\text { d I 4-hydroxyisoleucine }\end{array}$ & $\begin{array}{c}\mathrm{R}: \mathrm{BG} \text { reduction (from } 163.5 \mathrm{mg} / \mathrm{dL} \text { to } 143.6 \\
\mathrm{mg} / \mathrm{dL} \text { ), FSI reduction (from } 1.96 \mathrm{ng} / \mathrm{mL} \text { to } 1.52 \\
\mathrm{ng} / \mathrm{mL} \text { ), glucose tolerance improved }\end{array}$ & [58] \\
\hline & $\begin{array}{l}0.25 \mathrm{~g} \text { and } 0.5 \mathrm{~g} / \mathrm{kg} \text { b.w. } / \mathrm{d} / 14 \\
\mathrm{~d} \text { l ethanolic seeds extract }\end{array}$ & $\begin{array}{l}\text { R: serum glucose reduction (similar to } \\
\text { glibenclamide effect), TG reduction, TC } \\
\text { reduction, b.w. reduction ( } 5.5 \% \text { and } 9.5 \%)\end{array}$ & [118] \\
\hline & $\begin{array}{l}100 \mathrm{mg} / \mathrm{kg} \mathrm{b.w.} / \mathrm{d} / 4 \\
\mathrm{w} \text { I fenugreek extract }\end{array}$ & $\begin{array}{l}\text { R: BG reduction, level of liver enzymes } \\
\text { (aspartate aminotransferase and alanine } \\
\text { aminotransferase) reduction, TG reduction }\end{array}$ & [20] \\
\hline & $\begin{array}{l}500 \mathrm{mg} / \mathrm{d} \text { I } 30 \mathrm{~d} \text { or } 60 \mathrm{~d} \text { or } 90 \mathrm{~d} \text { I seed } \\
\text { extract enriched with } 40 \% \\
\text { furostanolic saponins }\end{array}$ & $\begin{array}{c}\text { H: FBG reduction }(6.69 \%, 10.31 \%, 21.98 \%) ; \\
\text { PPG }_{60 \min }(13.7 \%, 20.6 \%, 30.4 \%) \\
\mathrm{HbA}_{1 \mathrm{c}} \text { reduction }\end{array}$ & [119] \\
\hline & $1000 \mathrm{mg} / \mathrm{d} / 12 \mathrm{w}$ | seed extract & $\begin{array}{c}\text { H: FBG reduction }(24.62 \%), \mathrm{HbA}_{1 \mathrm{c}} \text { reduction } \\
(9.38 \%) ; \mathrm{TC} \text { reduction }(5.66 \%), \mathrm{TG} \text { reduction } \\
(17.23 \%), \text { LDL reduction }(4.15 \%)\end{array}$ & [120] \\
\hline \multirow{4}{*}{$\begin{array}{l}\text { Cinnamomum } \\
\text { zeylanicum J.Presl } \\
\text { Ceylon cinnamon }\end{array}$} & $\begin{array}{l}5 \mathrm{mg} \text { and } 10 \mathrm{mg} \text { and } 20 \mathrm{mg} / \mathrm{kg} \\
\text { b.w. } / \mathrm{d} \mid 45 \mathrm{~d} \text { I cinnamaldehyde }\end{array}$ & R: BG reduction $(60.8,139.3$ and $219.0 \mathrm{mg} / \mathrm{dL})$ & [62] \\
\hline & $\begin{array}{c}200 \mathrm{mg} / \mathrm{kg} \text { b.w. } / \mathrm{w} / 4 \\
\mathrm{w} / \text { ethanolic extract }\end{array}$ & $\begin{array}{c}\text { R: BG reduction (from } 257 \mathrm{mg} / \mathrm{dL} \text { to } 122.9 \\
\mathrm{mg} / \mathrm{dL}), \mathrm{HbA}_{1 \mathrm{c}} \text { reduction }(2.51 \%)\end{array}$ & [129] \\
\hline & $1 \mathrm{~g} / \mathrm{d} / 90 \mathrm{~d} /$ cinnamon supplement & $\begin{array}{l}\mathrm{H}: \mathrm{PPG}_{90 \mathrm{~min}} \text { reduced to } 224 \mathrm{mg} / \mathrm{dL} \text { (with } \\
\text { cinnamon) vs. reduced to } 270 \mathrm{mg} / \mathrm{dL} \\
\text { (without cinnamon) }\end{array}$ & [130] \\
\hline & $3000 \mathrm{mg} / \mathrm{d}$ / $8 \mathrm{w}$ I cinnamon powder & $\begin{array}{l}\text { H: SI reduction (by } 12.87 \mathrm{mIU} / \mathrm{L} \text { ), FBG reduction } \\
\text { (by } 0.45 \mathrm{mg} / \mathrm{dL} \text { ) }\end{array}$ & [131] \\
\hline
\end{tabular}


Table 3. Cont.

\begin{tabular}{|c|c|c|c|}
\hline Medicinal Plants & $\begin{array}{l}\text { Effective Dose, Intake Duration, } \\
\text { and Form of Plant Material }\end{array}$ & $\begin{array}{c}\text { Effects of Consumption in In Vivo Models } \\
\text { (Level of Change) }\end{array}$ & Source \\
\hline \multirow{8}{*}{$\begin{array}{l}\text { Zingiber officinale Rosc. } \\
\text { Ginger }\end{array}$} & $\begin{array}{c}25 \mathrm{mg} \text { and } 50 \mathrm{mg} \text { and } 100 \mathrm{mg} \text { and } 200 \\
\mathrm{mg} / \mathrm{kg} \text { b.w./ } \mathrm{I} \text { single } \\
\text { dose } \mathrm{I} \text { aqueous extract }\end{array}$ & $\begin{array}{l}\text { R: edemas reduction, NOx reduction similar } \\
\text { to indomethacin }\end{array}$ & [66] \\
\hline & $4 \mathrm{~mL} / \mathrm{kg}$ b.w. $/ \mathrm{d} \mid 6 \mathrm{w}$ I ginger juice & $\begin{array}{l}\text { R: flattening BG curve, flattening the } \\
\text { insulinemia curve }\end{array}$ & [148] \\
\hline & $\begin{array}{l}\text { 100-500 mg } / \mathrm{kg} \text { b.w. } / \mathrm{d} / 30 \\
\mathrm{~d} \text { I aqueous ginger extract }\end{array}$ & R: activity of glycolytic enzymes improved & [149] \\
\hline & $\begin{array}{c}200 \mathrm{mg} / \mathrm{kg} \text { b.w. } / \mathrm{d} \text { I } 30 \mathrm{~d} \text { I ethanolic } \\
\text { ginger extract }\end{array}$ & $\begin{array}{c}\text { R: reversed hyperglycaemia, activity of } \\
\text { extra-mitochondrial and intra-mitochondrial } \\
\text { enzymes improved }\end{array}$ & [150] \\
\hline & $1800 \mathrm{mg} / \mathrm{d}|8 \mathrm{w}|$ dried ginger & $\begin{array}{l}\text { H: BMI reduction }\left(0.54 \mathrm{~kg} / \mathrm{m}^{2}\right), \mathrm{HbA}_{1 \mathrm{c}}(1.11 \%) \\
\text { FBG (51.15 mg/dL), FSI }(7.88 \mathrm{mIU} / \mathrm{L}), \mathrm{TC}(31.10 \\
\mathrm{mg} / \mathrm{dL}), \text { LDL }(17.70 \mathrm{mg} / \mathrm{dL})\end{array}$ & [154] \\
\hline & $2 \mathrm{~g} / \mathrm{d}|12 \mathrm{w}|$ ginger powder & $\begin{array}{c}\mathrm{H} \text { : FBG reduction }(19,41 \mathrm{mg} / \mathrm{dL}) ; \mathrm{HbA}_{1 \mathrm{c}} \\
\text { reduction }(0.77 \%) ; \text { apolipoprotein } \mathrm{B} \text { reduction } \\
(12.45 \mathrm{mg} / \mathrm{dL})\end{array}$ & [155] \\
\hline & $3 \mathrm{~g} / \mathrm{d}|12 \mathrm{w}|$ ginger powder & $\begin{array}{l}\text { H: serum glucose reduction }(19.41 \mathrm{mg} / \mathrm{dL}) \text {, } \\
\mathrm{HbA} 1 \mathrm{c}(0.77 \%), \text { SI reduction }(1.46 \mu \mathrm{IU} / \mathrm{mL}) \text {, } \\
\text { insulin resistance reduction }(16.38) ; \\
\text { high-sensitive CRP reduction }(2.78 \mathrm{mg} / \mathrm{dL})\end{array}$ & [156] \\
\hline & $2 \mathrm{~g} / \mathrm{d}|8 \mathrm{w}|$ ginger powder & $\begin{array}{c}\text { H: SI reduction }(13 \mu \mathrm{U} / \mathrm{mL}), \text { LDL reduction } \\
(13.7 \%), \text { TG reduction }(11.7 \%), \text { HOMA-IR } \\
\text { reduction }(8.1 \%)\end{array}$ & [157] \\
\hline \multirow{4}{*}{$\begin{array}{l}\text { Phaseolus vulgaris L. } \\
\text { Common bean }\end{array}$} & $\begin{array}{l}200 \mathrm{mg} \text { and } 400 \mathrm{mg} / \mathrm{kg} \text { b.w. } / \mathrm{d} \mathrm{I} 28 \\
\mathrm{~d} \text { l aqueous ginger extract }\end{array}$ & R: GLUT-4 in skeletal muscles increase & [164] \\
\hline & $\begin{array}{l}100 \mathrm{mg} / \mathrm{kg} \text { b.w. } / \mathrm{d} \mid 2 \mathrm{w} \text { or } 4 \\
\mathrm{w} \text { l cooked common bean }\end{array}$ & R: FBG reduction ( $25 \%$ or $35 \%)$ & [163] \\
\hline & $\begin{array}{l}50 \mathrm{mg} \text { and } 100 \mathrm{mg} \text { and } 200 \mathrm{mg} \text { and } \\
250 \mathrm{mg} / \mathrm{kg} \text { b.w./ } \mathrm{I} 40 \mathrm{~d} / \text { aqueous } \\
\text { bean extract }\end{array}$ & $\begin{array}{c}\text { R: FBG reduction }(25 \% \text { or } 50 \%) \text {, TC reduction, } \\
\text { TG reduction }\end{array}$ & [165] \\
\hline & $300 \mathrm{mg} / \mathrm{kg}$ b.w./d I single dose I bean & $\begin{array}{l}\text { R: dose of glibenclamide reduction to } \\
\text { improve glycaemia }\end{array}$ & [166] \\
\hline \multirow{5}{*}{$\begin{array}{l}\text { Panax ginseng } \\
\text { C.A.Meyer } \\
\text { Ginseng }\end{array}$} & $\begin{array}{l}1500-3000 \mathrm{mg} / \mathrm{d} \text { I } 8 \mathrm{w} \text { / vinegar } \\
\text { ginseng extract }\end{array}$ & $\begin{array}{c}\mathrm{H}: \mathrm{HbA}_{1 \mathrm{c}} \text { reduction }(0.29-0.56 \%), \text { FBG reduction } \\
\quad(6.76-21.4 \mathrm{mg} / \mathrm{dL}) \text { compared to placebo }\end{array}$ & [187] \\
\hline & $\begin{array}{l}2 \text { capsules } / \mathrm{d}|8 \mathrm{w}| 30 \% \text { of } \\
\text { hydrolyzed ginseng extract }\end{array}$ & H: FBG reduction, $\mathrm{PPG}_{60 \mathrm{~min}}$ & [188] \\
\hline & $2.7 \mathrm{~g} / \mathrm{d}|4 \mathrm{w}|$ fermented ginseng & $\begin{array}{l}\mathrm{H}: \mathrm{PPG}_{120 \min } \text { reduction }(17.2 \%) \text {, glucose curve } \\
\text { flattened }(27.4 \%) \text {, no effect on FBG }\end{array}$ & [189] \\
\hline & $6 \mathrm{~g} / \mathrm{d}|12 \mathrm{w}|$ ginseng & $\begin{array}{l}\text { H: no effect on SI level, no effect on } \\
\text { insulin sensitivity }\end{array}$ & [190] \\
\hline & $6 \mathrm{~g} / \mathrm{d}|8 \mathrm{w}|$ ginseng & H: obesity level reduced & [191] \\
\hline
\end{tabular}

Despite their proven properties or traditional and historical medicinal successes, the presented raw materials are still only an adjunctive element in diabetes treatment and not the main agent in combating this disease. Undoubtedly, the biologically active substances contained in the discussed raw materials may considerably improve health status and prevent diabetes, especially type 2 diabetes. The fact that these raw materials are cheap, 
well known, and easily accessible on the European market should interest the inhabitants of developed countries.

Funding: Publication was co-financed within the framework of the Polish Ministry of Science and Higher Education's program: "Regional Initiative Excellence" in the years 2019-2022 (No. 005/RID/2018/19)"; financing amount 12000000 PLN.

Institutional Review Board Statement: Not applicable.

Informed Consent Statement: Not applicable.

Data Availability Statement: Not applicable.

Conflicts of Interest: The author declares no conflict of interest. The funders had no role in the design of the study; in the collection, analyses, or interpretation of data; in the writing of the manuscript, or in the decision to publish the results.

\section{Abbreviations}

EFSA

BMI

$\mathrm{HbA}_{1 \mathrm{c}}$

FBG

TC

TG

$\mathrm{H}_{2} \mathrm{O}_{2}$

SI

FSI

ROS

NF-K $\beta$

$\mathrm{NADH}$

HOMA-IR

GLUT-4

GLUT-1

$\mathrm{PPG}_{60 \mathrm{~min}}$

$\mathrm{PPG}_{30 \mathrm{~min}}$

$\mathrm{PPG}_{120 \mathrm{~min}}$

OGTT

NOAEL

$\mathrm{DPPH}$

ABTS

FRAP

LDL

UCP-1

PPAR- $\alpha$

CRP

FDA
European Food Safety Authority

body mass index

glycated hemoglobin

fasting blood glucose

total cholesterol

triglycerides

hydrogen

per-

ox-

ide

serum

in-

sulin

fasting

serum

in-

sulin

reactive

oxy-

gen

species

nuclear

factor-

$\kappa \beta$

nicotinamide adenine dinucleotide + hydrogen

homeostasis model assessment insulin resistance

glucose transporter type 4

glucose transporter type 1

postprandial glucose level (60 $\mathrm{min})$

postprandial glucose level (30 $\mathrm{min})$

postprandial glucose level (120 min)

oral glucose tolerance test

not observed adverse effect level

2,2-diphenyl-1-picrylhydrazyl

2,2'-azino-bis(3-ethylbenzothiazoline-6-sulfonic acid)

ferric reducing antioxidant power

low-density lipoprotein

uncoupling protein 1

peroxisome proliferator-activated receptor alpha

C-reactive protein

Food and Drug Administration 


\section{References}

1. Alem Geberemeskel, G.; Godefa Debebe, Y.; Abraha Nguse, N. Clinical study antidiabetic effect of fenugreek seed powder solution (Trigonella foenum-graecum L.) on hyperlipidemia in diabetic patients. J. Diabetes Res. 2019, 2019, 8507453. [CrossRef]

2. Statista Diabetics Percentage Worldwide. 2019. Available online: https://www.statista.com/statistics/271464/percentage-ofdiabetics-worldwide/ (accessed on 2 November 2020).

3. Shaw, J.E.; Sicree, R.A.; Zimmet, P.Z. Global estimates of the prevalence of diabetes for 2010 and 2030. Diabetes Res. Clin. Pract. 2010, 87, 4-14. [CrossRef]

4. Roglic, G.; Unwin, N. Mortality attributable to diabetes: Estimates for the year 2010. Diabetes Res. Clin. Pract. 2010, 87, 15-19. [CrossRef]

5. Wu, Z.; Tang, Y.; Cheng, Q. Diabetes increases the mortality of patients with COVID-19: A meta-analysis. Acta Diabetol. 2021, 58, 139-144. [CrossRef] [PubMed]

6. Szczepaniak, O.; Ligaj, M.; Kobus-Cisowska, J.; Tichoniuk, M.; Dziedziński, M.; Przeor, M.; Szulc, P. The genoprotective role of naringin. Biomolecules 2020, 10, 700. [CrossRef] [PubMed]

7. Dziedzinski, M.; Kobus-Cisowska, J.; Szymanowska, D.; Stuper-Szablewska, K.; Baranowska, M. Identification of polyphenols from coniferous shoots as natural antioxidants and antimicrobial compounds. Molecules 2020, 25, 3527. [CrossRef] [PubMed]

8. Telichowska, A.; Kobus-Cisowska, J.; Szulc, P. Phytopharmacological possibilities of bird cherry Prunus padus L. and Prunus serotina L. species and their bioactive phytochemicals. Nutrients 2020, 12, 1966. [CrossRef]

9. Kobus-Cisowska, J.; Szymanowska-Powałowska, D.; Szczepaniak, O.; Kmiecik, D.; Przeor, M.; Gramza-Michałowska, A.; Cielecka-Piontek, J.; Smuga-Kogut, M.; Szulc, P. Composition and in vitro effects of cultivars of Humulus lupulus L. Hops on cholinesterase activity and microbial growth. Nutrients 2019, 11, 1377. [CrossRef] [PubMed]

10. Szczepaniak, O.M.; Kobus-Cisowska, J.; Kusek, W.; Przeor, M. Functional properties of Cornelian cherry (Cornus mas L.): A comprehensive review. Eur. Food Res. Technol. 2019, 245, 2071-2087. [CrossRef]

11. Przeor, M.; Flaczyk, E.; Beszterda, M.; Szymandera-Buszka, K.E.; Piechocka, J.; Kmiecik, D.; Szczepaniak, O.; Kobus-Cisowska, J.; Jarzębski, M.; Tylewicz, U. Air-drying temperature changes the content of the phenolic acids and flavonols in white mulberry (Morus alba L.) leaves. Cienc. Rural 2019, 49. [CrossRef]

12. Tylewicz, U.; Oliveira, G.; Alminger, M.; Nohynek, L.; Dalla Rosa, M.; Romani, S. Antioxidant and antimicrobial properties of organic fruits subjected to PEF-assisted osmotic dehydration. Innov. Food Sci. Emerg. Technol. 2020, 62, 102341. [CrossRef]

13. Cavalcanti, V.P.; Aazza, S.; Bertolucci, S.K.V.; Pereira, M.M.A.; Cavalcanti, P.P.; Buttrós, V.H.T.; de Oliveira e Silva, A.M.; Pasqual, M.; Dória, J. Plant, pathogen and biocontrol agent interaction effects on bioactive compounds and antioxidant activity in garlic. Physiol. Mol. Plant Pathol. 2020, 112, 101550. [CrossRef]

14. Tajner-Czopek, A.; Gertchen, M.; Rytel, E.; Kita, A.; Kucharska, A.Z.; Sokół-Łętowska, A. Study of antioxidant activity of some medicinal plants having high content of caffeic acid derivatives. Antioxidants 2020, 9, 412. [CrossRef] [PubMed]

15. Waśkiewicz, A.; Beszterda, M.; Bocianowski, J.; Goliński, P. Natural occurrence of fumonisins and ochratoxin A in some herbs and spices commercialized in Poland analyzed by UPLC-MS/MS method. Food Microbiol. 2013, 36, 426-431. [CrossRef] [PubMed]

16. Sowa, P.; Marcinčáková, D.; Miłek, M.; Sidor, E.; Legáth, J.; Dżugan, M. Analysis of cytotoxicity of selected asteraceae plant extracts in real time, their antioxidant properties and polyphenolic profile. Molecules 2020, 25, 5517. [CrossRef]

17. Kozlowska, M.; Zbikowska, A.; Marciniak-Lukasiak, K.; Kowalska, M. Herbal extracts incorporated into shortbread cookies: Impact on color and fat quality of the cookies. Biomolecules 2019, 9, 858. [CrossRef]

18. Przeor, M.; Flaczyk, E.; Kmiecik, D.; Kobus-Cisowska, J.; Bueschke, M.; Kulczyński, B. Polish consumers' awareness and knowledge about functional food. Univ. Technol. Stetin. Agric. Aliment. Pisc. Zootech 2018, 341, 59-68. [CrossRef]

19. Musabayane, C.T.; Bwititi, P.T.; Ojewole, J.A.O. Effects of oral administration of some herbal extracts on food consumption and blood glucose levels in normal and streptozotocin-treated diabetic rats. Methods Find. Exp. Clin. Pharmacol. 2006, 28, $223-228$. [CrossRef] [PubMed]

20. Baset, M.; Ali, T.; Elshamy, H.; El Sadek, A.; Sami, D.; Badawy, M.; Abou-Zekry, S.; Heiba, H.; Saadeldin, M.; Abdellatif, A. Anti-diabetic effects of fenugreek (Trigonella foenum-graecum): A comparison between oral and intraperitoneal-An animal study. Int. J. Funct. Nutr. 2020, 1, 2. [CrossRef]

21. Salehi, B.; Ata, A.; Anil Kumar, N.V.; Sharopov, F.; Ramírez-Alarcón, K.; Ruiz-Ortega, A.; Abdulmajid Ayatollahi, S.; Tsouh Fokou, P.V.; Kobarfard, F.; Amiruddin Zakaria, Z.; et al. Antidiabetic potential of medicinal plants and their active components. Biomolecules 2019, 9, 551. [CrossRef]

22. Singab, A.N.; Youssef, F.S.; Ashour, M.L. Medicinal plants with potential antidiabetic activity and their assessment. Med. Aromat. Plants 2014, 3, 151. [CrossRef]

23. Arumugam, G.; Manjula, P.; Paari, N. A review: Anti diabetic medicinal plants used for diabetes mellitus. J. Acute Dis. 2013, 2, 196-200. [CrossRef]

24. Chhetri, D.R.; Parajuli, P.; Subba, G.C. Antidiabetic plants used by Sikkim and Darjeeling Himalayan tribes, India. J. Ethnopharmacol. 2005, 99, 199-202. [CrossRef] [PubMed]

25. Przeor, M.; Flaczyk, E.; Kmiecik, D.; Buchowski, M.S.; Staniek, H.; Tomczak-Graczyk, A.; Kobus-Cisowska, J.; GramzaMichałowska, A.; Foksowicz-Flaczyk, J. Functional properties and antioxidant activity of Morus alba L. leaves var. Zolwinska Wielkolistna (WML-P)—the effect of controlled conditioning process. Antioxidants 2020, 9, 668. [CrossRef] 
26. Chinsembu, K.C. Diabetes mellitus and nature's pharmacy of putative antidiabetic plants. J. Herb. Med. 2019, 15, 100230. [CrossRef]

27. Durazzo, A.; D’Addezio, L.; Camilli, E.; Piccinelli, R.; Turrini, A.; Marletta, L.; Marconi, S.; Lucarini, M.; Lisciani, S.; Gabrielli, P.; et al. From plant compounds to botanicals and back: A current snapshot. Molecules 2018, 23, 1844. [CrossRef] [PubMed]

28. Chan, C.H.; Ngoh, G.C.; Yusoff, R. A brief review on anti diabetic plants: Global distribution, active ingredients, extraction techniques and acting mechanisms. Pharmacogn. Rev. 2012, 6, 22-28. [CrossRef]

29. Eddouks, M.; Maghrani, M.; Lemhadri, A.; Ouahidi, M.L.; Jouad, H. Ethnopharmacological survey of medicinal plants used for the treatment of diabetes mellitus, hypertension and cardiac diseases in the south-east region of Morocco (Tafilalet). J. Ethnopharmacol. 2002, 82, 97-103. [CrossRef]

30. Gholap, S.; Kar, A. Hypoglycaemic effects of some plant extracts are possibly mediated through inhibition in corticosteroid concentration. Pharmazie 2004, 59, 876-878.

31. Heidari, R.; Zareae, S.; Heidarizadeh, M. Extraction, purification, and inhibitory effect of alpha-amylase inhibitor from wheat (Triticum aestivum Var. Zarrin). Pakistan J. Nutr. 2005, 4, 101-105. [CrossRef]

32. Miura, T.; Itoh, C.; Iwamoto, N.; Kato, M.; Kawai, M.; Park, S.R.; Suzuki, I. Hypoglycemic activity of the fruit of the Momordica charantia in type 2 diabetic mice. J. Nutr. Sci. Vitaminol. 2001, 47, 340-344. [CrossRef] [PubMed]

33. Crespy, V.; Williamson, G. A review of the health effects of green tea catechins in in vivo animal models. J. Nutr. 2004, 134. [CrossRef] [PubMed]

34. Bnouham, M.; Ziyyat, A.; Mekhfi, H.; Tahri, A.; Legssyer, A. Medicinal plants with potential antidiabetic activity-A review of ten years of herbal medicine research (1990-2000). Int J Diabetes Metab. 2006, 14, 1-25. [CrossRef]

35. Kim, M.J.; Ryu, G.R.; Chung, J.S.; Sim, S.S.; Rhie, D.J.; Yoon, S.H.; Hahn, S.J.; Kim, M.S.; Jo, Y.H. Protective effects of epicatechin against the toxic effects of streptozotocin on rat pancreatic islets: In vivo and in vitro. Pancreas 2003, 26, 292-299. [CrossRef] [PubMed]

36. Mukherjee, P.K.; Maiti, K.; Mukherjee, K.; Houghton, P.J. Leads from Indian medicinal plants with hypoglycemic potentials. J. Ethnopharmacol. 2006, 106, 1-28. [CrossRef] [PubMed]

37. Esmaeili, M.A.; Yazdanparast, R. Hypoglycaemic effect of Teucrium polium: Studies with rat pancreatic islets. J. Ethnopharmacol. 2004, 95, 27-30. [CrossRef]

38. Kaneto, H.; Matsuoka, T.; Nakatani, Y.; Kawamori, D.; Matsuhisa, M.; Yamasaki, Y. Oxidative stress and the JNK pathway in diabetes. Curr. Diabetes Rev. 2005, 1, 65-72. [CrossRef]

39. Shin, A.H.; Oh, C.J.; Park, J.-P. Glycation-induced inactivation of antioxidant enzymes and modulation of cellular redox status in lens cells. Arch. Pharmacal Res. 2006, 29, 577-581. [CrossRef]

40. Suryavanshi, S.V.; Kulkarni, Y.A. NF-k $\beta$ : A potential target in the management of vascular complications of diabetes. Front. Pharmacol. 2017, 8, 798. [CrossRef]

41. Herrera, T.; Navarro del Hierro, J.; Fornari, T.; Reglero, G.; Martin, D. Inhibitory effect of quinoa and fenugreek extracts on pancreatic lipase and $\alpha$-amylase under in vitro traditional conditions or intestinal simulated conditions. Food Chem. 2019, 270, 509-517. [CrossRef] [PubMed]

42. Xiao, J.; Ni, X.; Kai, G.; Chen, X. A review on structure-activity relationship of dietary polyphenols inhibiting $\alpha$-amylase. Crit. Rev. Food Sci. Nutr. 2013, 53, 497-506. [CrossRef] [PubMed]

43. Ali, H.; Houghton, P.J.; Soumyanath, A. $\alpha$-Amylase inhibitory activity of some Malaysian plants used to treat diabetes; with particular reference to Phyllanthus amarus. J. Ethnopharmacol. 2006, 107, 449-455. [CrossRef] [PubMed]

44. Ozkan, G.; Kamiloglu, S.; Ozdal, T.; Boyacioglu, D.; Capanoglu, E. Potential use of Turkish medicinal plants in the treatment of various diseases. Molecules 2016, 21, 257. [CrossRef]

45. Kumari, R.; Srivastava, S.; Srivastava, R.P. Nutritional evaluation of fresh leaves of mulberry genotypes. Agric. Sci. Dig. 2009, 29, 198-201. [CrossRef]

46. Seneta, W.; Dolatowski, J. Dendrologia; Wydawnictwo Naukowe PWN: Warsaw, Poland, 2007.

47. Przeor, M.; Flaczyk, E. Antioxidant properties of Paratha type flat bread enriched with white mulberry leaf extract. Indian J. Tradit. Knowl. 2016, 15, 237-244.

48. Kobus-Cisowska, J.; Gramza-Michalowska, A.; Kmiecik, D.; Flaczyk, E.; Korczak, J. Mulberry fruit as an antioxidant component in muesli. Agric. Sci. 2013, 4, 130-135. [CrossRef]

49. Kobus-Cisowska, J.; Dziedziński, M.; Szymanowska, D.; Szczepaniak, O.; Byczkiewicz, S.; Telichowska, A.; Szulc, P. The effects of Morus alba L. fortification on the quality, functional properties and sensory attributes of bread stored under refrigerated conditions. Sustainability 2020, 12, 6691. [CrossRef]

50. Przeor, M.; Flaczyk, E. Morwa biała-Nieocenione znaczenie zdrowotne. Przem. Spożywczy 2016, 5, 33-35. [CrossRef]

51. Grześkowiak, J.; Łochyńska, M. Związki biologicznie aktywne morwy białej (Morus alba L.) i ich działanie lecznicze. Postępy Fitoter. 2017, 18, 31-35.

52. Butt, M.S.; Nazir, A.; Sultan, M.T.; Schroën, K. Morus alba L. nature's functional tonic. Trends Food Sci. Technol. 2008, 19, 505-512. [CrossRef]

53. Kwon, H.J.; Chung, J.Y.; Kim, J.Y.; Kwon, O. Comparison of 1-deoxynojirimycin and aqueous mulberry leaf extract with emphasis on postprandial hypoglycemic effects: In vivo and in vitro studies. J. Agric. Food Chem. 2011, 59, 3014-3019. [CrossRef] 
54. Yin, Z.; Zhang, W.; Feng, F.; Zhang, Y.; Kang, W. $\alpha$-Glucosidase inhibitors isolated from medicinal plants. Food Sci. Hum. Wellness 2014, 3, 136-174. [CrossRef]

55. Liu, Q.; Li, X.; Li, C.; Zheng, Y.; Peng, G. 1-Deoxynojirimycin alleviates insulin resistance via activation of insulin signaling $\mathrm{PI} 3 K / A K T$ pathway in skeletal muscle of $\mathrm{db} / \mathrm{db}$ mice. Molecules 2015, 20, 21700-21714. [CrossRef]

56. Pandey, V.K.; Mathur, A.; Khan, M.F.; Kakkar, P. Activation of PERK-eIF2 $\alpha$-ATF4 pathway contributes to diabetic hepatotoxicity: Attenuation of ER stress by Morin. Cell. Signal. 2019, 59, 41-52. [CrossRef] [PubMed]

57. Shane-McWhorter, L. Biological complementary therapies: A focus on botanical products in diabetes. Diabetes Spectr. 2001, 14, 199-208. [CrossRef]

58. Broca, C.; Gross, R.; Petit, P.; Sauvaire, Y.; Manteghetti, M.; Tournier, M.; Masiello, P.; Gomis, R.; Ribes, G. 4-hydroxyisoleucine: Experimental evidence of its insulinotropic and antidiabetic properties. Am. J. Physiol.-Endocrinol. Metab. 1999, 277, E617-E623. [CrossRef] [PubMed]

59. Sanlier, N.; Gencer, F. Role of spices in the treatment of diabetes mellitus: A minireview. Trends Food Sci. Technol. 2020, 99, 441-449. [CrossRef]

60. Yoshinari, O.; Igarashi, K. Anti-diabetic effect of trigonelline and nicotinic acid, on KK-Ay Mice. Curr. Med. Chem. 2010, 17, 2196-2202. [CrossRef] [PubMed]

61. Jarvill-Taylor, K.J.; Anderson, R.A.; Graves, D.J. A hydroxychalcone derived from cinnamon functions as a mimetic for insulin in 3T3-L1 adipocytes. J. Am. Coll. Nutr. 2001, 20, 327-336. [CrossRef]

62. Subash Babu, P.; Prabuseenivasan, S.; Ignacimuthu, S. Cinnamaldehyde-A potential antidiabetic agent. Phytomedicine 2007, 14, 15-22. [CrossRef]

63. Santos, H.O.; da Silva, G.A.R. To what extent does cinnamon administration improve the glycemic and lipid profiles? Clin. Nutr. ESPEN 2018, 27, 1-9. [CrossRef]

64. Singh, P.; Jayaramaiah, R.H.; Agawane, S.B.; Vannuruswamy, G.; Korwar, A.M.; Anand, A.; Dhaygude, V.S.; Shaikh, M.L.; Joshi, R.S.; Boppana, R.; et al. Potential dual role of eugenol in inhibiting advanced glycation end products in diabetes: Proteomic and mechanistic insights. Sci. Rep. 2016, 6, 18798. [CrossRef] [PubMed]

65. Ali, B.H.; Blunden, G.; Tanira, M.O.; Nemmar, A. Some phytochemical, pharmacological and toxicological properties of ginger (Zingiber officinale Roscoe): A review of recent research. Food Chem. Toxicol. 2008, 46, 409-420. [CrossRef]

66. Ezzat, S.M.; Ezzat, M.I.; Okba, M.M.; Menze, E.T.; Abdel-Naim, A.B. The hidden mechanism beyond ginger (Zingiber officinale Rosc.) potent in vivo and in vitro anti-inflammatory activity. J. Ethnopharmacol. 2018, 214, 113-123. [CrossRef]

67. Chavan, J.J.; Kshirsagar, P.R.; Pai, S.R.; Pawar, N.V. Micropropagation, metabolite profiling, antioxidant activities and chromatographic determination of bioactive molecules across in vitro conditions and subsequent field cultivation stages of 'Shampoo Ginger' (Zingiber zerumbet L. Roscoe ex Sm). Biocatal. Agric. Biotechnol. 2018, 16, 79-89. [CrossRef]

68. Tran, N.; Pham, B.; Le, L. Bioactive compounds in anti-diabetic plants: From herbal medicine to modern drug discovery. Biology 2020, 9, 252. [CrossRef] [PubMed]

69. Huang, Y.-C.; Lin, C.-Y.; Huang, S.-F.; Lin, H.-C.; Chang, W.-L.; Chang, T.-C. Effect and mechanism of ginsenosides CK and Rg1 on stimulation of glucose uptake in 3T3-L1 adipocytes. J. Agric. Food Chem. 2010, 58, 6039-6047. [CrossRef]

70. Kim, K.-S.; Yang, H.J.; Lee, I.-S.; Kim, K.-H.; Park, J.; Jeong, H.-S.; Kim, Y.; Ahn, K.S.; Na, Y.-C.; Jang, H.-J. The aglycone of ginsenoside Rg3 enables glucagon-like peptide-1 secretion in enteroendocrine cells and alleviates hyperglycemia in type 2 diabetic mice OPEN. Sci. Rep. 2015, 5, 18325. [CrossRef]

71. Tian, W.; Chen, L.; Zhang, L.; Wang, B.; Li, X.; Fan, K.; Ai, C.; Xia, X.; Li, S.; Li, Y. Effects of ginsenoside Rg1 on glucose metabolism and liver injury in streptozotocin-induced type 2 diabetic rats. Genet. Mol. Res. 2017, 16, 16019463. [CrossRef] [PubMed]

72. Merck I Poland. Available online: https://www.sigmaaldrich.com/PL/pl (accessed on 13 December 2021).

73. Yuan, Q.; Xie, Y.; Wang, W.; Yan, Y.; Ye, H.; Jabbar, S.; Zeng, X. Extraction optimization, characterization and antioxidant activity in vitro of polysaccharides from mulberry (Morus alba L.) leaves. Carbohydr. Polym. 2015, 128, 52-62. [CrossRef] [PubMed]

74. Flaczyk, E.; Kobus-Cisowska, J.; Przeor, M.; Korczak, J.; Remiszewski, M.; Korbas, E.; Buchowski, M. Chemical characterization and antioxidative properties of Polish variety of Morus alba L. leaf aqueous extracts from the laboratory and pilot-scale processes. Agric. Sci. 2013, 4, 141-147. [CrossRef]

75. Zhang, D.-Y.; Wan, Y.; Hao, J.-Y.; Hu, R.-Z.; Chen, C.; Yao, X.-H.; Zhao, W.-G.; Liu, Z.-Y.; Li, L. Evaluation of the alkaloid, polyphenols, and antioxidant contents of various mulberry cultivars from different planting areas in eastern China. Ind. Crop. 2018, 122, 298-307. [CrossRef]

76. Cheng, K.C.; Wang, C.J.; Chang, Y.C.; Hung, T.W.; Lai, C.J.; Kuo, C.W.; Huang, H.P. Mulberry fruits extracts induce apoptosis and autophagy of liver cancer cell and prevent hepatocarcinogenesis in vivo. J. Food Drug Anal. 2020, 28, 84-93. [CrossRef] [PubMed]

77. Riche, D.M.; Riche, K.D.; East, H.E.; Barrett, E.K.; May, W.L. Impact of mulberry leaf extract on type 2 diabetes (Mul-DM): A randomized, placebo-controlled pilot study. Complement. Ther. Med. 2017, 32, 105-108. [CrossRef] [PubMed]

78. Li, F.; Zhang, B.; Chen, G.; Fu, X. The novel contributors of anti-diabetic potential in mulberry polyphenols revealed by UHPLC-HR-ESI-TOF-MS/MS. Food Res. Int. 2017, 100, 873-884. [CrossRef] [PubMed]

79. Ranjan, B.; Kumar, R.; Verma, N.; Mittal, S.; Pakrasi, P.L.; Venkatesh Kumar, R. Evaluation of the antidiabetic properties of S-1708 mulberry variety. Pharmacogn. Mag. 2017, 13, S280-S288. [CrossRef]

80. Gryn-Rynko, A.; Bazylak, G.; Olszewska-Slonina, D. New potential phytotherapeutics obtained from white mulberry (Morus alba L.) leaves. Biomed. Pharmacother. 2016, 84, 628-636. [CrossRef] 
81. Harauma, A.; Murayama, T.; Ikeyama, K.; Sano, H.; Arai, H.; Takano, R.; Kita, T.; Hara, S.; Kamei, K.; Yokode, M. Mulberry leaf powder prevents atherosclerosis in apolipoprotein E-deficient mice. Biochem. Biophys. Res. Commun. 2007, 358, 751-756. [CrossRef]

82. Rodrigues, E.L.; Marcelino, G.; Silva, G.T.; Figueiredo, P.S.; Garcez, W.S.; Corsino, J.; Guimarães, R.D.C.A.; Freitas, K.D.C. Nutraceutical and medicinal potential of the Morus species in metabolic dysfunctions. Int. J. Mol. Sci. 2019, 20, 301. [CrossRef] [PubMed]

83. Hwang, J.Y.; Sung, W.C.; Shyu, Y.S. Effect of mulberry lees addition on dough mixing characteristics and the quality of mulberry toast. J. Mar. Sci. Technol. 2008, 16, 103-108. [CrossRef]

84. Wen, P.; Hu, T.-G.; Linhardt, R.J.; Liao, S.-T.; Wu, H.; Zou, Y.-X. Mulberry: A review of bioactive compounds and advanced processing technology. Trends Food Sci. Technol. 2019, 83, 138-158. [CrossRef]

85. Akhtar, N.; Hisham, J.; Shoaib Khan, H.M.; Ali Khan, B.; Mahmood, T.; Saeed, T. Whitening and antierythemic effect of a cream containing Morus alba extract. Hygeia J. Drugs Med. 2012, 4, 97-103.

86. Adisakwattana, S.; Intrawangso, J.; Hemrid, A.; Chanathong, B.; Mäkynen, K. Extracts of edible plants inhibit pancreatic lipase cholesterol esterase and cholesterol micellization, and bind bile acids. Food Technol. Biotechnol. 2012, 50, 11-16.

87. Adisakwattana, S.; Ruengsamran, T.; Kampa, P.; Sompong, W. In vitro inhibitory effects of plant-based foods and their combinations on intestinal $\alpha$-glucosidase and pancreatic $\alpha$-amylase. BMC Complement. Altern. Med. 2012, 12, 110. [CrossRef] [PubMed]

88. Lim, H.H.; Yang, S.J.; Kim, Y.; Lee, M.; Lim, Y. Combined treatment of mulberry leaf and fruit extract ameliorates obesity-related inflammation and oxidative stress in high fat diet-induced obese mice. J. Med. Food 2013, 16, 673-680. [CrossRef] [PubMed]

89. Mahboubi, M. Morus alba (mulberry), a natural potent compound in management of obesity. Pharmacol. Res. 2019, 146, 104341. [CrossRef] [PubMed]

90. Peng, C.H.; Liu, L.K.; Chuang, C.M.; Chyau, C.C.; Huang, C.N.; Wang, C.J. Mulberry water extracts possess an anti-obesity effect and ability to inhibit hepatic lipogenesis and promote lipolysis. J. Agric. Food Chem. 2011, 59, 2663-2671. [CrossRef] [PubMed]

91. Tond, S.B.; Fallah, S.; Salemi, Z.; Seifi, M. Influence of mulberry leaf extract on serum adiponectin, visfatin and lipid profile levels in type 2 diabetic rats. Brazilian Arch. Biol. Technol. 2016, 59, 16160297. [CrossRef]

92. Ann, J.Y.; Eo, H.; Lim, Y. Mulberry leaves (Morus alba L.) ameliorate obesity-induced hepatic lipogenesis, fibrosis, and oxidative stress in high-fat diet-fed mice. Genes Nutr. 2015, 10, 46. [CrossRef]

93. Liu, L.K.; Lee, H.J.; Shih, Y.W.; Chyau, C.C.; Wang, C.J. Mulberry anthocyanin extracts inhibit LDL oxidation and macrophagederived foam cell formation induced by oxidative LDL. J. Food Sci. 2008, 73, H113-H121. [CrossRef]

94. Katsube, T.; Yamasaki, M.; Shiwaku, K.; Ishijima, T.; Matsumoto, I.; Abe, K.; Yamasaki, Y. Effect of flavonol glycoside in mulberry (Morus alba L.) leaf on glucose metabolism and oxidative stress in liver in diet-induced obese mice. J. Sci. Food Agric. 2010, 90, 2386-2392. [CrossRef]

95. Metwally, F.M.; Ahmed, H.H.; Rashad, H.; Zaazaa, A.M. Insights into the role of Morus alba in reversing obesity-associated hepatic steatosis and related metabolic disorder in rats. Asian J. Pharm. Clin. Res. 2016, 9, 231-238. [CrossRef]

96. Ren, C.; Zhang, Y.; Cui, W.; Lu, G.; Wang, Y.; Gao, H.; Huang, L.; Mu, Z. A polysaccharide extract of mulberry leaf ameliorates hepatic glucose metabolism and insulin signaling in rats with type 2 diabetes induced by high fat-diet and streptozotocin. Int. J. Biol. Macromol. 2015, 72, 951-959. [CrossRef] [PubMed]

97. Cai, S.; Sun, W.; Fan, Y.; Guo, X.; Xu, G.; Xu, T.; Hou, Y.; Zhao, B.; Feng, X.; Liu, T. Effect of mulberry leaf (Folium Mori) on insulin resistance via IRS-1/PI3K/Glut-4 signalling pathway in type 2 diabetes mellitus rats. Pharm. Biol. 2016, 54, 2685-2691. [CrossRef]

98. Sudha, P.; Zinjarde, S.S.; Bhargava, S.Y.; Kumar, A.R. Potent a-amylase inhibitory activity of Indian Ayurvedic medicinal plants. BMC Complement. Altern. Med. 2011, 11, 5. [CrossRef]

99. Kimura, T.; Nakagawa, K.; Kubota, H.; Kojima, Y.; Goto, Y.; Yamgishi, K.; Oita, S.; Oikawa, S.; Miyazawa, T. Food-grade mulberry powder enriched with 1-deoxynojirimycin suppresses the elevation of postprandial blood glucose in humans. J. Agric. Food Chem. 2007, 55, 5869-5874. [CrossRef] [PubMed]

100. Hansawasdi, C.; Kawabata, J. $\alpha$-Glucosidase inhibitory effect of mulberry (Morus alba) leaves on Caco-2. Fitoterapia 2006, 77, 568-573. [CrossRef]

101. Jiao, Y.; Wang, X.; Jiang, X.; Kong, F.; Wang, S.; Yan, C. Antidiabetic effects of Morus alba fruit polysaccharides on high-fat dietand streptozotocin-induced type 2 diabetes in rats. J. Ethnopharmacol. 2017, 199, 119-127. [CrossRef] [PubMed]

102. Hu, T.G.; Wen, P.; Liu, J.; Long, X.S.; Liao, S.T.; Wu, H.; Zou, Y.X. Combination of mulberry leaf and oat bran possessed greater hypoglycemic effect on diabetic mice than mulberry leaf or oat bran alone. J. Funct. Foods 2019, 61, 103503. [CrossRef]

103. Li, Y.; Zhang, X.; Liang, C.; Hu, J.; Yu, Z. Safety evaluation of mulberry leaf extract: Acute, subacute toxicity and genotoxicity studies. Regul. Toxicol. Pharmacol. 2018, 95, 220-226. [CrossRef]

104. EU Novel Food Catalogue (v.1.1). Available online: https://ec.europa.eu/food/safety/novel_food/catalogue/search/public/ index.cfm (accessed on 4 November 2020).

105. Wani, S.A.; Kumar, P. Fenugreek: A review on its nutraceutical properties and utilization in various food products. J. Saudi Soc. Agric. Sci. 2018, 17, 97-106. [CrossRef]

106. Ahmad, A.; Alghamdi, S.S.; Mahmood, K.; Afzal, M. Fenugreek a multipurpose crop: Potentialities and improvements. Saudi J. Biol. Sci. 2016, 23, 300-310. [CrossRef] [PubMed] 
107. El Nasri, N.A.; El Tinay, A.H. Functional properties of fenugreek (Trigonella foenum graecum) protein concentrate. Food Chem. 2007, 103, 582-589. [CrossRef]

108. Acharya, S.; Srichamroen, A.; Basu, S.; Ooraikul, B.; Basu, T. Improvement in the nutraceutical properties of fenugreek (Trigonella foenum-graecum L.). Songklanakarin J. Sci. Technol. 2006, 28, 1-9.

109. He, Y.; Ding, C.; Wang, X.; Wang, H.; Suo, Y. Using response surface methodology to optimize countercurrent chromatographic separation of polyphenol compounds from fenugreek (Trigonella foenum-graecum L.) seeds. J. Liq. Chromatogr. Relat. Technol. 2015, 38, 29-35. [CrossRef]

110. Gaur, V.; Bodhankar, S.L.; Mohan, V.; Thakurdesai, P.A. Neurobehavioral assessment of hydroalcoholic extract of Trigonella foenum-graecum seeds in rodent models of Parkinson's disease. Pharm. Biol. 2013, 51, 550-557. [CrossRef]

111. Król-Kogus, B.; Krauze-Baranowska, M. Kozieradka pospolita (Trigonella foenum graecum L.)—tradycja stosowania na tle wyników badań naukowych. Postępy Fitoter. 2011, 3, 185-190.

112. Kumar, P.; Bhandari, U.; Jamadagni, S. Fenugreek seed extract inhibit fat accumulation and ameliorates dyslipidemia in high fat diet-induced obese rats. Biomed. Res. Int. 2014, 2014, 606021. [CrossRef]

113. Kaviarasan, S.; Naik, G.H.; Gangabhagirathi, R.; Anuradha, C.V.; Priyadarsini, K.I. In vitro studies on antiradical and antioxidant activities of fenugreek (Trigonella foenum graecum) seeds. Food Chem. 2007, 103, 31-37. [CrossRef]

114. Kania, M.; Derebecka, N. Medicinal plants in type 2 diabetes mellitus. Postępy Fitoter. 2010, 2, 76-84.

115. Rao, M.U.; Sreenivasulu, M.; Chengaiah, B.; Reddy, K.J.; Chetty, C.M. Herbal medicines for diabetes mellitus: A review. Int. J. PharmTech Res. 2010, 2, 1883-1892.

116. Bawadi, H.A.; Maghaydah, S.N.; Tayyem, R.F.; Tayyem, R.F. The postprandial hypoglycemic activity of fenugreek seed and seeds' extract in type 2 diabetics: A pilot study. Pharmacogn. Mag. 2009, 4, 134-138.

117. Arivalagan, M.; Gangopadhyay, K.K.; Kumar, G. Determination of steroidal saponins and fixed oil content in fenugreek (Trigonella foenum-graecum) genotypes. Indian J. Pharm. Sci. 2013, 75, 110-113. [CrossRef]

118. Eidi, A.; Eidi, M.; Sokhteh, M. Effect of fenugreek (Trigonella foenum-graecum L) seeds on serum parameters in normal and streptozotocin-induced diabetic rats. Nutr. Res. 2007, 27, 728-733. [CrossRef]

119. Verma, N.; Usman, K.; Patel, N.; Jain, A.; Dhakre, S.; Swaroop, A.; Bagchi, M.; Kumar, P.; Preuss, H.G.; Bagchi, D. A multicenter clinical study to determine the efficacy of a novel fenugreek seed (Trigonella foenum-graecum) extract (Fenfuro ${ }^{\mathrm{TM}}$ ) in patients with type 2 diabetes. Food Nutr. Res. 2016, 60, 32382. [CrossRef]

120. Singh, A.; Rai, J.; Mahajan, D.S. Comparative evaluation of glipizide and fenugreek (Trigonella foenum-graecum) seeds as monotherapy and combination therapy on glycaemic control and lipid profile in patients with type 2 diabetes mellitus. Int. J. Basic Clin. Pharmacol. 2016, 3, 942-950. [CrossRef]

121. Fæste, C.K.; Namork, E.; Lindvik, H. Allergenicity and antigenicity of fenugreek (Trigonella foenum-graecum) proteins in foods. J. Allergy Clin. Immunol. 2009, 123, 187-194. [CrossRef]

122. Ouzir, M.; El Bairi, K.; Amzazi, S. Toxicological properties of fenugreek (Trigonella foenum graecum). Food Chem. Toxicol. 2016, 96, 145-154. [CrossRef]

123. Momtaz, S.; Hassani, S.; Khan, F.; Ziaee, M.; Abdollahi, M. Cinnamon, a promising prospect towards Alzheimer's disease. Pharmacol. Res. 2018, 130, 241-258. [CrossRef] [PubMed]

124. Tapsell, L.C.; Hemphill, I.; Cobiac, L.; Patch, C.S.; Sullivan, D.R.; Fenech, M.; Roodenrys, S.; Keogh, J.B.; Clifton, P.M.; Williams, P.G.; et al. Health benefits of herbs and spices: The past, the present, the future. Med. J. Aust. 2006, 185, 1-24. [CrossRef]

125. Vasconcelos, N.G.; Croda, J.; Simionatto, S. Antibacterial mechanisms of cinnamon and its constituents: A review. Microb. Pathog. 2018, 120, 198-203. [CrossRef]

126. Chanotiya, C.S.; Yadav, A. Enantioenriched (3s)-(+)-linalool in the leaf oil of cinnamomum tamala nees et eberm. From Kumaon. J. Essent. Oil Res. 2010, 22, 593-596. [CrossRef]

127. Wang, Y.; Zhang, Y.; Shi, Y.; Pan, X.; Lu, Y.; Cao, P. Antibacterial effects of cinnamon (Cinnamomum zeylanicum) bark essential oil on Porphyromonas gingivalis. Microb. Pathog. 2018, 116, 26-32. [CrossRef]

128. Lu, M.; Yuan, B.; Zeng, M.; Chen, J. Antioxidant capacity and major phenolic compounds of spices commonly consumed in China. Food Res. Int. 2011, 44, 530-536. [CrossRef]

129. Sharafeldin, K.; Rizvi, M.R. Effect of traditional plant medicines (Cinnamomum zeylanicum and Syzygium cumini) on oxidative stress and insulin resistance in streptozotocin-induced diabetic rats. J. Basic Appl. Zool. 2015, 72, 126-134. [CrossRef]

130. Mirfeizi, M.; Mehdizadeh Tourzani, Z.; Mirfeizi, S.Z.; Asghari Jafarabadi, M.; Rezvani, H.R.; Afzali, M. Controlling type 2 diabetes mellitus with herbal medicines: A triple-blind randomized clinical trial of efficacy and safety. J. Diabetes 2016, 8, 647-656. [CrossRef] [PubMed]

131. Vafa, M.; Mohammadi, F.; Shidfar, F.; Sormaghi, M.S.; Heidari, I.; Golestan, B.; Amiri, F. Effects of cinnamon consumption on glycemic status, lipid profile and body composition in type 2 diabetic patients. Int. J. Prev. Med. 2012, 3, 531-536.

132. Unlu, M.; Ergene, E.; Unlu, G.V.; Zeytinoglu, H.S.; Vural, N. Composition, antimicrobial activity and in vitro cytotoxicity of essential oil from Cinnamomum zeylanicum Blume (Lauraceae). Food Chem. Toxicol. 2010, 48, 3274-3280. [CrossRef] [PubMed]

133. Qadir, M.M.F.; Bhatti, A.; Ashraf, M.U.; Sandhu, M.A.; Anjum, S.; John, P. Immunomodulatory and therapeutic role of Cinnamomum verum extracts in collagen-induced arthritic BALB/c mice. Inflammopharmacology 2018, 26, 157-170. [CrossRef] [PubMed] 
134. Kamath, J.V.; Rana, A.C.; Roy Chowdhury, A. Pro-healing effect of Cinnamomum zeylanicum bark. Phyther. Res. 2003, 17, 970-972. [CrossRef]

135. Jamali, N.; Jalali, M.; Saffari-Chaleshtori, J.; Samare-Najaf, M.; Samareh, A. Effect of cinnamon supplementation on blood pressure and anthropometric parameters in patients with type 2 diabetes: A systematic review and meta-analysis of clinical trials. Diabetes Metab. Syndr. Clin. Res. Rev. 2020, 14, 119-125. [CrossRef] [PubMed]

136. Zachariah, T.J. Ginger. In Chemistry of Spices; Parthasarathy, V.A., Chempakam, B., Zachariah, T.J., Eds.; CABI: London, UK, 2008; pp. 70-97, ISBN 1845934059.

137. An, K.; Zhao, D.; Wang, Z.; Wu, J.; Xu, Y.; Xiao, G. Comparison of different drying methods on Chinese ginger (Zingiber officinale Roscoe): Changes in volatiles, chemical profile, antioxidant properties, and microstructure. Food Chem. 2016, 197, 1292-1300. [CrossRef]

138. Malhotra, S.; Singh, A.P. Medicinal properties of Ginger (Zingiber officinale Rosc.). Nat. Prod. Radiance $2003,2,296-301$.

139. Shanmugam, K.R.; Mallikarjuna, K.; Nishanth, K.; Kuo, C.H.; Reddy, K.S. Protective effect of dietary ginger on antioxidant enzymes and oxidative damage in experimental diabetic rat tissues. Food Chem. 2011, 124, 1436-1442. [CrossRef]

140. Young, H.Y.; Luo, Y.L.; Cheng, H.Y.; Hsieh, W.C.; Liao, J.C.; Peng, W.H. Analgesic and anti-inflammatory activities of [6]-gingerol. J. Ethnopharmacol. 2005, 96, 207-210. [CrossRef] [PubMed]

141. Elshater, A.-E.A.; Salman, M.M.A.; Moussa, M.M.A. Effect of Ginger Extract Consumption on levels of blood Glucose, Lipid Profile and Kidney Functions in Alloxan Induced-Diabetic Rats. Egypt. Acad. J. Biol. Sci 2009, 2, 153-162. [CrossRef]

142. Sheikhhossein, F.; Borazjani, M.; Jafari, A.; Askari, M.; Vataniyan, E.; Gholami, F.; Amini, M.R. Effects of ginger supplementation on biomarkers of oxidative stress: A systematic review and meta-analysis of randomized controlled trials. Clin. Nutr. ESPEN 2021, 45, 111-119. [CrossRef] [PubMed]

143. Bhandari, U.; Sharma, J.N.; Zafar, R. The protective action of ethanolic ginger (Zingiber officinale) extract in cholesterol fed rabbits. J. Ethnopharmacol. 1998, 61, 167-171. [CrossRef]

144. Funk, J.L.; Frye, J.B.; Oyarzo, J.N.; Chen, J.; Zhang, H.; Timmermann, B.N. Anti-inflammatory effects of the essential oils of ginger (Zingiber officinale Roscoe) in experimental rheumatoid arthritis. PharmaNutrition 2016, 4, 123-131. [CrossRef]

145. Jafarzadeh, A.; Nemati, M. Therapeutic potentials of ginger for treatment of Multiple sclerosis: A review with emphasis on its immunomodulatory, anti-inflammatory and anti-oxidative properties. J. Neuroimmunol. 2018, 324, 54-75. [CrossRef]

146. Haksar, A.; Sharma, A.; Chawla, R.; Kumar, R.; Arora, R.; Singh, S.; Prasad, J.; Gupta, M.; Tripathi, R.P.; Arora, M.P.; et al. Zingiber officinale exhibits behavioral radioprotection against radiation-induced CTA in a gender-specific manner. Pharmacol. Biochem. Behav. 2006, 84, 179-188. [CrossRef]

147. Ryan, J.L.; Morrow, G.R. Ginger. Oncol. Nurse Ed. 2010, 24, 46. [PubMed]

148. Akhani, S.P.; Vishwakarma, S.L.; Goyal, R.K. Anti-diabetic activity of Zingiber officinale in streptozotocin-induced type I diabetic rats. J. Pharm. Pharmacol. 2004, 56, 101-105. [CrossRef] [PubMed]

149. Abdulrazaq, N.B.; Cho, M.; Win, N.N.; Zaman, R.; Rahman, M.T. Beneficial effects of ginger (Zingiber officinale) on carbohydrate metabolism in streptozotocin-induced diabetic rats. Br. J. Nutr. 2012, 108, 1194-1201. [CrossRef] [PubMed]

150. Ramudu, S.K.; Korivi, M.; Kesireddy, N.; Lee, L.-C.; Cheng, I.-S.; Kuo, C.-H.; Kesireddy, S.R. Nephro-protective effects of a ginger extract on cytosolic and mitochondrial enzymes against streptozotocin (STZ)-induced diabetic complications in rats. Chin. J. Physiol. 2011, 54, 79-86. [CrossRef]

151. Akash, M.S.H.; Rehman, K.; Tariq, M.; Chen, S. Zingiber officinale and type 2 diabetes mellitus: Evidence from experimental studies. Crit. Rev. Eukaryot. Gene Expr. 2015, 25, 91-112. [CrossRef]

152. Rani, M.P.; Krishna, M.S.; Padmakumari, K.P.; Raghu, K.G.; Sundaresan, A. Zingiber officinale extract exhibits antidiabetic potential via modulating glucose uptake, protein glycation and inhibiting adipocyte differentiation: An in vitro study. J. Sci. Food Agric. 2012, 92, 1948-1955. [CrossRef] [PubMed]

153. Li, Y.; Tran, V.H.; Duke, C.C.; Roufogalis, B.D. Gingerols of Zingiber officinale enhance glucose uptake by increasing cell surface GLUT4 in cultured L6 myotubes. Planta Med. 2012, 78, 1549-1555. [CrossRef]

154. El Gayar, M.H.; Aboromia, M.M.M.; Ibrahim, N.A.; Abdel Hafiz, M.H. Effects of ginger powder supplementation on glycemic status and lipid profile in newly diagnosed obese patients with type 2 diabetes mellitus. Obes. Med. 2019, 14, 100094. [CrossRef]

155. Khandouzi, N.; Shidfar, F.; Rajab, A.; Rahideh, T.; Hosseini, P.; Taheri, M.M. The effects of Ginger on fasting blood sugar, hemoglobin A1c, apolipoprotein B, apolipoprotein A-I and malondialdehyde in type 2 diabetic patients. Iran. J. Pharm. Res. 2015, 14, 131-140.

156. Shidfar, F.; Rajab, A.; Rahideh, T.; Khandouzi, N.; Hosseini, S.; Shidfar, S. The effect of ginger (Zingiber officinale) on glycemic markers in patients with type 2 diabetes. J. Complement. Integr. Med. 2015, 12, 165-170. [CrossRef] [PubMed]

157. Mahluji, S.; Attari, V.E.; Mobasseri, M.; Payahoo, L.; Ostadrahimi, A.; Golzari, S.E. Effects of ginger (Zingiber officinale) on plasma glucose level, HbA1c and insulin sensitivity in type 2 diabetic patients. Int. J. Food Sci. Nutr. 2013, 64, 682-686. [CrossRef]

158. Li, Y.; Tran, V.H.; Duke, C.C.; Roufogalis, B.D. Preventive and protective properties of Zingiber officinale (Ginger) in diabetes mellitus, diabetic complications, and associated lipid and other metabolic disorders: A brief review. Evid.-Based Complement. Altern. Med. 2012, 2012, 516870. [CrossRef]

159. Popowski, D.; Pawłowska, K.A.; Deipenbrock, M.; Hensel, A.; Kruk, A.; Melzig, M.F.; Piwowarski, J.P.; Granica, S. Antiadhesive activity of hydroethanolic extract from bean pods of Phaseolus vulgaris (common bean) against uropathogenic E. coli and permeability of its constituents through Caco-2 cells monolayer. J. Ethnopharmacol. 2021, 274, 114053. [CrossRef] 
160. Madrera, R.R.; Negrillo, A.C.; Valles, B.S.; Fernández, J.J.F. Phenolic content and antioxidant activity in seeds of common bean (Phaseolus vulgaris L.). Foods 2021, 10, 864. [CrossRef]

161. Bljajić, K.; Brajković, A.; Čačić, A.; Vujić, L.; Jablan, J.; Carvalho, I.S.D.; Končić, M.Z. Chemical composition, antioxidant, and $\alpha$-glucosidase-inhibiting activity of aqueous and hydroethanolic extracts of traditional antidiabetics from Croatian ethnomedicine. Horticulturae 2021, 7, 15. [CrossRef]

162. Damián-Medina, K.; Salinas-Moreno, Y.; Milenkovic, D.; Figueroa-Yáñez, L.; Marino-Marmolejo, E.; Higuera-Ciapara, I.; VallejoCardona, A.; Lugo-Cervantes, E. In silico analysis of antidiabetic potential of phenolic compounds from blue corn (Zea mays L.) and black bean (Phaseolus vulgaris L.). Heliyon 2020, 6, e03632. [CrossRef]

163. Lomas-Soria, C.; Pérez-Ramírez, I.F.; Caballero-Pérez, J.; Guevara-Gonzalez, R.G.; Guevara-Olvera, L.; Loarca-Piña, G.; GuzmanMaldonado, H.S.; Reynoso-Camacho, R. Cooked common beans (Phaseolus vulgaris L.) modulate renal genes in streptozotocininduced diabetic rats. J. Nutr. Biochem. 2015, 26, 761-768. [CrossRef]

164. Halenova, T.; Raksha, N.; Kravchenko, O.; Vovk, T.; Yurchenko, A.; Vareniuk, I.; Savchuk, O.; Ostapchenko, L. Hypoglycemic activity of Phaseolus vulgaris (L.) aqueous extract in type 1 diabetic rats. Curr. Issues Pharm. Med. Sci. 2019, 32, 210-218. [CrossRef]

165. Almuaigel, M.F.; Seif, M.A.; Albuali, H.W.; Alharbi, O.; Alhawash, A. Hypoglycemic and hypolipidemic effects of aqueous extract of Phaseolus vulgaris pods in streptozotocin-diabetic rats. Biomed. Pharmacother. 2017, 94, 742-746. [CrossRef]

166. Ocho-Anin Atchibri, A.L.; Brou, K.D.; Kouakou, T.H.; Kouadio, Y.J.; Gnakri, D. Screening for antidiabetic activity and phytochemical constituents of common bean (Phaseolus vulgaris L.) seeds. J. Med. Plants Res. 2010, 4, 1757-1761. [CrossRef]

167. Shi, Z.; Zhang, X.; Zhu, Y.; Yao, Y.; Ren, G. Natural extracts from white common bean (Phaseolus vulgaris L.) inhibit 3T3-L1 adipocytes differentiation. Appl. Sci. 2020, 11, 167. [CrossRef]

168. Karłowicz-Bodalska, K. Żeń-szeń-wszechlek Dalekiego Wschodu. Postęoy Fitoter. 2004, 4, 183-188.

169. Wolski, T.; Ludwiczuk, A.; Baj, T.; Głowniak, K.; Świątek, Ł. Rodzaj Panax—systematyka, skład chemiczny, działanie i zastosowanie oraz analiza fitochemiczna nadziemnych i podziemnych organów żeń-szenia amerykańskiego-Panax quinquefolium L. Cz. I. Postępy Fitoter. 2008, 2, 96-114.

170. Park, H.J.; Kim, D.H.; Park, S.J.; Kim, J.M.; Ryu, J.H. Ginseng in traditional herbal prescriptions. J. Ginseng Res. 2012, 36, $225-241$. [CrossRef]

171. Lee, J.H.; Kim, S.C.; Lee, H.Y.; Cho, D.Y.; Jung, J.G.; Kang, D.; Kang, S.S.; Cho, K.M. Changes in nutritional compositions of processed mountain-cultivated ginseng sprouts (Panax ginseng) and screening for their antioxidant and anti-inflammatory properties. J. Funct. Foods 2021, 86, 104668. [CrossRef]

172. Guo, N.; Yang, Y.; Yang, X.; Guan, Y.; Yang, J.; Quan, J.; Yan, H.; Hou, W.; Zhang, G. Growth age of mountain cultivated ginseng affects its chemical composition. Ind. Crops Prod. 2021, 167, 113531. [CrossRef]

173. Qi, H.; Zhang, Z.; Liu, J.; Chen, Z.; Huang, Q.; Li, J.; Chen, J.; Wang, M.; Zhao, D.; Wang, Z.; et al. Comparisons of isolation methods, structural features, and bioactivities of the polysaccharides from three common Panax species: A review of recent progress. Molecules 2021, 26, 4997. [CrossRef] [PubMed]

174. Liu, L.; Xu, F.R.; Wang, Y.Z. Traditional uses, chemical diversity and biological activities of Panax L. (Araliaceae): A review. J. Ethnopharmacol. 2020, 263, 112792. [CrossRef]

175. Szczuka, D.; Nowak, A.; Zakłos-Szyda, M.; Kochan, E.; Szymańska, G.; Motyl, I.; Blasiak, J. American ginseng (Panax quinquefolium L.) as a source of bioactive phytochemicals with pro-health properties. Nutrients 2019, 11, 1041. [CrossRef]

176. Fan, S.; Zhang, Z.; Su, H.; Xu, P.; Qi, H.; Zhao, D.; Li, X. Panax ginseng clinical trials: Current status and future perspectives. Biomed. Pharmacother. 2020, 132, 110832. [CrossRef]

177. Dzimitrowicz, A.; Cyganowski, P.; Pohl, P.; Milkowska, W.; Jermakowicz-Bartkowiak, D.; Jamroz, P. Plant extracts activated by cold atmospheric pressure plasmas as suitable tools for synthesis of gold nanostructures with catalytic uses. Nanomaterials 2020, 10, 1088. [CrossRef] [PubMed]

178. Panossian, A.; Abdelfatah, S.; Efferth, T. Network pharmacology of ginseng (Part II): The differential effects of red ginseng and ginsenoside $\operatorname{Rg} 5$ in cancer and heart diseases as determined by transcriptomics. Pharmaceuticals 2021, 14, 1010. [CrossRef]

179. Chou, C.-K.; Huang, Y.-S.; Lin, P.-Y.; Imai, K.; Chen, S.-M.; Lee, J.-A. The ginsenoside Rg1 rescues mitochondrial disorders in aristolochic acid-induced nephropathic mice. Life 2021, 11, 1018. [CrossRef] [PubMed]

180. Kim, H.J.; Park, K.H.; Kim, D.H.; Chae, H.J.; Sung, G.H.; Kim, Y.O. In vitro assessments of bone microcomputed tomography in an aged male rat model supplemented with Panax ginseng. Saudi J. Biol. Sci. 2018, 25, 1135-1139. [CrossRef]

181. Hwang, J.H.; Park, S.H.; Choi, E.K.; Jung, S.J.; Pyo, M.K.; Chae, S.W. A randomized, double-blind, placebo-controlled pilot study to assess the effects of protopanaxadiol saponin-enriched ginseng extract and pectinase-processed ginseng extract on the prevention of acute respiratory illness in healthy people. J. Ginseng Res. 2020, 44, 697-703. [CrossRef]

182. Lee, S.T.; Chu, K.; Sim, J.Y.; Heo, J.H.; Kim, M. Panax ginseng enhances cognitive performance in Alzheimer disease. Alzheimer Dis. Assoc. Disord. 2008, 22, 222-226. [CrossRef]

183. Cui, Y.; Shu, X.-O.; Gao, Y.-T.; Cai, H.; Tao, M.-H.; Zheng, W. Association of ginseng use with survival and quality of life among breast cancer patients. Am. J. Epidemiol. 2006, 163, 645-653. [CrossRef]

184. Jung, S.J.; Hwang, J.H.; Park, S.H.; Choi, E.K.; Ha, K.C.; Baek, H.I.; Shin, D.G.; Seo, J.H.; Chae, S.W. A 12-week, randomized, double-blind study to evaluate the efficacy and safety of liver function after using fermented ginseng powder (GBCK25). Food Nutr. Res. 2020, 64. [CrossRef] 
185. Kochan, E.; Nowak, A.; Zakłos-Szyda, M.; Szczuka, D.; Szymańska, G.; Motyl, I. Panax quinquefolium L. ginsenosides from hairy root cultures and their clones exert cytotoxic, genotoxic and pro-apoptotic activity towards human colon adenocarcinoma cell line Caco-2. Molecules 2020, 25, 2262. [CrossRef]

186. Tardy, A.L.; De Fer, B.B.; Cañigueral, S.; Kennedy, D.; Scholey, A.; Hitier, S.; Aran, A.; Pouteau, E. Reduced self-perception of fatigue after intake of Panax ginseng root extract $\left(\mathrm{G} 115^{\circledR}\right)$ formulated with vitamins and minerals—an open-label study. Int. J. Environ. Res. Public Health 2021, 18, 6257. [CrossRef]

187. Yoon, J.W.; Kang, S.M.; Vassy, J.L.; Shin, H.; Lee, Y.H.; Ahn, H.Y.; Choi, S.H.; Park, K.S.; Jang, H.C.; Lim, S. Efficacy and safety of ginsam, a vinegar extract from Panax ginseng, in type 2 diabetic patients: Results of a double-blind, placebo-controlled study. $J$. Diabetes Investig. 2012, 3, 309-317. [CrossRef]

188. Park, S.H.; Oh, M.R.; Choi, E.K.; Kim, M.G.; Ha, K.C.; Lee, S.K.; Kim, Y.G.; Park, B.H.; Kim, D.S.; Soo-Wan, C. An 8-wk, randomized, double-blind, placebo-controlled clinical trial for the antidiabetic effects of hydrolyzed ginseng extract. J. Ginseng Res. 2014, 38, 239-243. [CrossRef] [PubMed]

189. Oh, M.-R.; Park, S.-H.; Kim, S.-Y.; Back, H.-I.; Kim, M.-G.; Jeon, J.-Y.; Ha, K.-C.; Na, W.-T.; Cha, Y.-S.; Park, B.-H.; et al. Postprandial glucose-lowering effects of fermented red ginseng in subjects with impaired fasting glucose or type 2 diabetes: A randomized, double-blind, placebo-controlled clinical trial. BMC Complement. Altern. Med. 2014, 14, 237. [CrossRef]

190. Hye Cho, Y.; Cheol Ahn, S.; Yeoup Lee, S.; Wook Jeong, D.; Jung Choi, E.; Jin Kim, Y.; Gyu Lee, J.; Lee, Y.-H.; Shin OMD, B.-C. Effect of Korean red ginseng on insulin sensitivity in non-diabetic healthy overweight and obese adults. Asia Pac. J. Clin. Nutr. 2013, 22, 365-371. [CrossRef]

191. Kwon, D.H.; Bose, S.; Song, M.Y.; Lee, M.J.; Lim, C.Y.; Kwon, B.S.; Kim, H.J. Efficacy of Korean red ginseng by single nucleotide polymorphism in obese women: Randomized, double-blind, placebo-controlled trial. J. Ginseng Res. 2012, 36, 176. [CrossRef]

192. Zhu, J.; Chen, H.; Song, Z.; Wang, X.; Sun, Z. Effects of ginger (Zingiber officinale Roscoe) on type 2 diabetes mellitus and components of the metabolic syndrome: A systematic review and meta-analysis of randomized controlled trials. Evid.-Based Complement. Altern. Med. 2018, 2018, 5692962. [CrossRef]

193. Jeon, W.J.; Oh, J.S.; Park, M.S.; Ji, G.E. Anti-hyperglycemic effect of fermented ginseng in type 2 diabetes mellitus mouse model. Phyther. Res. 2013, 27, 166-172. [CrossRef]

194. Kim, S.T.; Kim, H.B.; Lee, K.H.; Choi, Y.R.; Kim, H.J.; Shin, I.S.; Gyoung, Y.S.; Joo, S.S. Steam-dried ginseng berry fermented with Lactobacillus plantarum controls the increase of blood glucose and body weight in type 2 obese diabetic db/db mice. J. Agric. Food Chem. 2012, 60, 5438-5445. [CrossRef]

195. Raposo, A.; Saraiva, A.; Ramos, F.; Carrascosa, C.; Raheem, D.; Bárbara, R.; Silva, H. The role of food supplementation in microcirculation-A comprehensive review. Biology 2021, 10, 616. [CrossRef] 